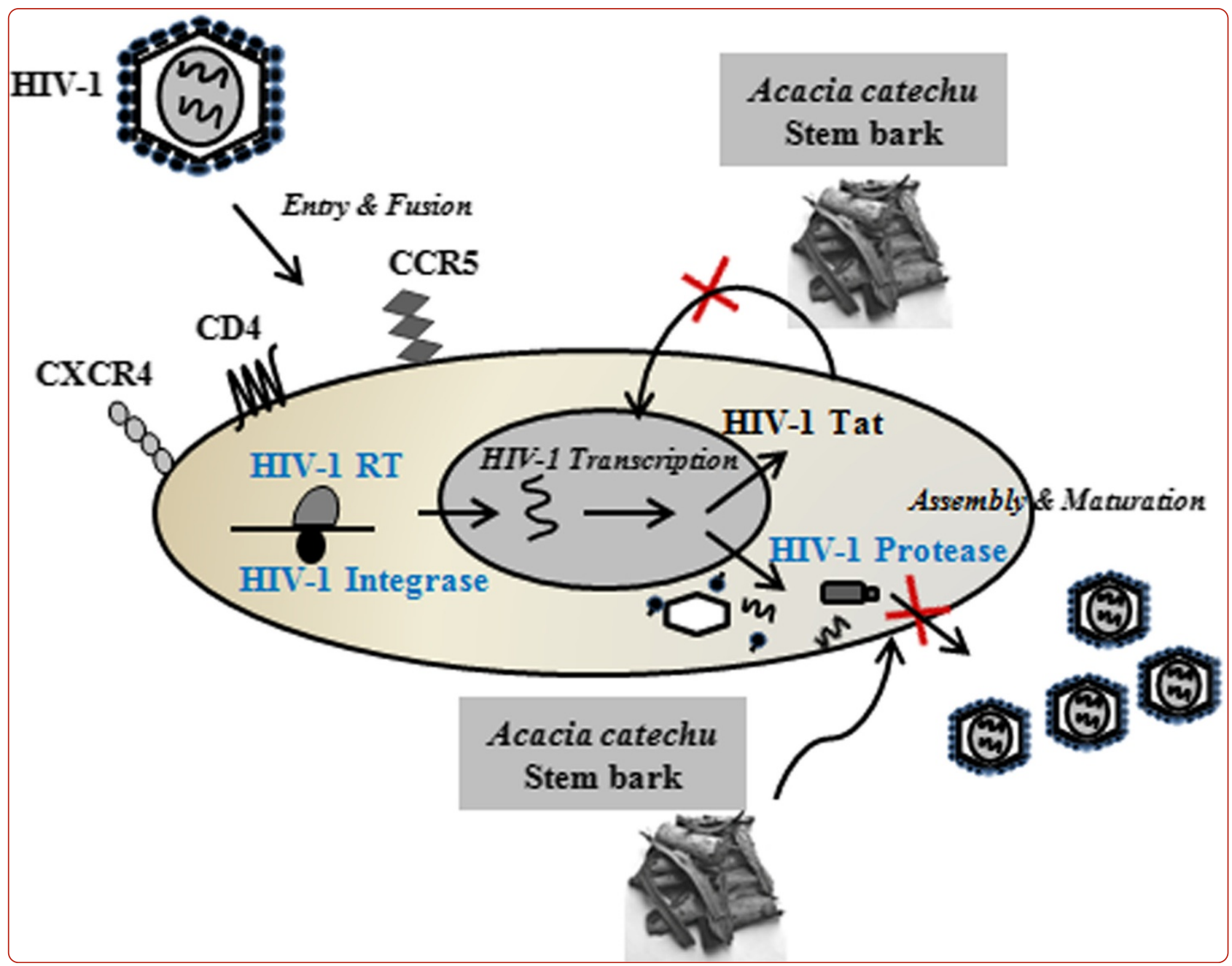

Extracts from Acacia catechu suppress HIV-1 replication by inhibiting the activities of the viral protease and Tat

Nutan et al.

C Biomed Central 


\title{
Extracts from Acacia catechu suppress HIV-1 replication by inhibiting the activities of the viral protease and Tat
}

Nutan ${ }^{1}$, Manoj Modi ${ }^{1}$, Charlene S Dezzutti ${ }^{2}$, Shweta Kulshreshtha ${ }^{3}$, Ajay Kumar Singh Rawat ${ }^{3}$, Sharad Kumar Srivastava ${ }^{3}$, Swadesh Malhotra ${ }^{3}$, Anjali Verma ${ }^{4}$, Udaykumar Ranga ${ }^{4}$ and Satish Kumar Gupta ${ }^{{ }^{*}}$

\begin{abstract}
Background: Acacia catechu (Mimosa family) stem bark extracts have been used traditionally as a dietary supplement as well as a folk medicine given its reported anti-inflammatory, immunomodulatory, hepatoprotective, antioxidant, anti-microbial and anti-tumor activities. The present study was undertaken to evaluate the anti-HIV-1 activity of the extracts from stem bark of $A$. catechu.

Methods: The aqueous and 50\% ethanolic extracts of A. catechu stem bark were prepared and 50\% ethanolic extract was further fractioned by successively partitioning with petroleum ether, chloroform and n-butanol. All the extracts and fractions were evaluated for cytotoxicity and anti-HIV-1 activity using different in vitro assays. The active n-butanol fraction was evaluated for its inhibition against HIV-1 reverse transcriptase, integrase, protease, pro-viral genome integration and viral Tat protein mediated transactivation. The effect of n-butanol fraction on the induction of pro-inflammatory cytokines secretion in Vk2/E6E7 cells and transepithelial resistance in Caco-2 and HEC-1A cells was investigated.

Results: The aqueous and $50 \%$ ethanolic extracts of $A$. catechu showed $I C_{50}$ values of $1.8 \pm 0.18 \mu \mathrm{g} / \mathrm{ml}$ and $3.6 \pm 0.31 \mu \mathrm{g} / \mathrm{ml}$, respectively in cell-free virus based assay using TZM-bl cells and HIV-1 ${ }_{\text {NL4.3 }}$ (X-4 tropic). In the above assay, $\mathrm{n}$-butanol fraction exhibited anti-HIV-1 activity with an $\mathrm{IC}_{50}$ of $1.7 \pm 0.12 \mu \mathrm{g} / \mathrm{ml}$. The $\mathrm{n}$-butanol fraction showed a dose-dependent inhibition against HIV-1 ${ }_{N L 4.3}$ infection of the peripheral blood lymphocytes and against

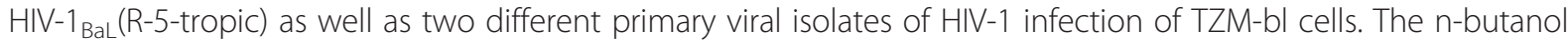
fraction demonstrates a potent inhibitory activity against the viral protease $\left(\mathrm{IC}_{50}=12.9 \mu \mathrm{g} / \mathrm{ml}\right)$, but not reverse transcriptase or integrase. Further, in Alu-PCR no effect on viral integration was observed. The n-butanol fraction interfered with the Tat-mediated Long Terminal Repeat transactivation in TZM-bl cells, mRNA quantitation (qRT-PCR) and electrophoretic mobility shift assay (EMSA). The n-butanol fraction did not cause an enhanced secretion of pro-inflammatory cytokines in Vk2/E6E7 cells. Additionally, no adverse effects were observed to the monolayer formed by the Caco-2 and HEC-1A epithelial cells.
\end{abstract}

Conclusions: The results presented here show a potential anti-HIV-1 activity of A. catechu mediated by the inhibition of the functions of the viral protein and Tat.

\footnotetext{
* Correspondence: skgupta@nii.ac.in

${ }^{1}$ Reproductive Cell Biology Laboratory, National Institute of Immunology,

Aruna Asaf Ali Marg, New Delhi 110 067, India

Full list of author information is available at the end of the article
} 


\section{Background}

Highly active antiretroviral therapy (HAART) has led to a dramatic increase in the longevity and the quality of life for people infected with HIV-1 [1], but due to the emergence of drug resistant virus [2], there is a continuous need to develop new anti-HIV-1 agents with novel targets and mechanisms of action. Topical application of micobicides not only prevents the viral infection at the portal of entry but also may empower women with decision making. Since natural products have an enormous structural diversity and provide a large reservoir for new therapeutic/preventive regimens, exploring them for the targets against HIV-1 infection is a promising option [3-6].

The early events in HIV-1 life-cycle comprise of the viral attachment to the host cell surface followed by the conversion of the viral RNA genome into proviral DNA by the virally-encoded enzyme, reverse transcriptase (RT), and its integration in the host genome by the virallyencoded enzyme integrase $[7,8]$. The provirus integrated in the host genome may remain in a quiescent state in the resting lymphocytes until basal transcription produces a threshold level of the viral trans-activator protein, Tat. As Tat accumulates above the threshold, it leads to the transition from latent state of $\mathrm{HIV}-1$ to active replication in lymphocytes when the protein interacts with the Tatresponsive element (TAR) located in the long terminal repeat (LTR) promoter in the viral DNA [9-11]. Extracellular Tat has also been implicated in acquired immunodeficiency syndrome (AIDS) and AIDS-associated pathologies [12]. The late events of the viral life cycle include the processes of HIV-1 mRNA synthesis, protein expression and virus maturation. The progeny viruses expressed from the activated viral gene expression are assembled on and budded through the host cell membrane after being processed by the viral encoded enzyme protease [7]. Compounds that block activation or suppression of the viral gene expression have a therapeutic potential for extension of latency or inhibition of persistent progressive infection. Discovering drugs that interfere with the functionality of the crucial enzymes of HIV-1 that play a critical role in viral pathogenesis i.e. RT, integrase and protease are important targets to be considered against HIV-1 infection.

Acacia catechu, commonly known as catechu, cachou and black cutch is an important medicinal plant, especially prevalent in Asia. It is an extensively studied plant. A wide spectrum of compounds that have been isolated and characterized from $A$. catechu include 4-hydroxybenzoic acid, kaempferol, quercetin, 3,4',7-trihydroxyl-3',5-dimethoxyflavone, catechin, rutin, isorhamnetin, epicatechin, afzelechin, epiafzelechin, mesquitol, ophioglonin, aromadendrin and phenol [13]. Catechins, rutin and isorhamnetin exhibit antioxidant property by scavenging free-radicals [14]. The flavonoid rich extract of $A$. catechu mainly comprised of catechins demonstrated anti-inflammatory activity by reducing the production of pro-inflammatory eicosanoids [15] as well as immunomodulatory property with a significant effect on cell mediated and humoral immunity against foreign antigens $[16,17]$. The methanolic extract of this plant possesses antimicrobial activity against different species of pathogenic and non-pathogenic microorganisms [18] as well as DNA protective activities [19]. Anti-fertility activity of a traditional contraceptive pill comprising A. catechu has also been reported [20].

In context of the ethnopharmacological importance of A. catechu, we screened its aqueous and ethanolic extracts for anti-HIV-1 activity. Further, the active n-butanol fraction was studied for its ability to block HIV-1 infection and the possible mechanisms of action.

\section{Results}

Cytotoxicity and anti-HIV-1 activity of extracts, fractions and compounds from $A$. catechu

Our interest was to systematically evaluate aqueous and 50\% ethanolic extracts prepared from stem bark of A. catechu for activity against HIV-1 after their initial characterization. Multiple peaks were observed in the reverse phase HPLC profiles of both aqueous as well as $50 \%$ ethanolic extracts of $A$. catechu stem bark, at an isocratic gradient (Additional file 1: Figure S1). The 50\% ethanolic extract appeared to be more complex as compared to that of aqueous extract. The initial screening for anti-HIV-1 activity of the $A$. catechu extracts was performed using reporter-gene based TZM-bl cells. Extracts were first screened for their impact on cellular viability. $\mathrm{CC}_{50}$ is the concentration of the extracts that reduced the cell viability by $50 \%$. The $50 \%$ ethanolic extract showed $\mathrm{CC}_{50}$ at $371.0 \pm 11.7 \mu \mathrm{g} / \mathrm{ml}$ whereas the aqueous extract was non-toxic up to $400 \mu \mathrm{g} / \mathrm{ml}$ for TZM-bl cells (Table 1). A dose-dependent inhibition in $\mathrm{HIV}-1_{\mathrm{NL} 4.3}$ infection by the aqueous as well as $50 \%$ ethanolic extracts was observed (Figure 1). The 50\%

\section{Table 1 Cytotoxicity and anti-HIV-1 activity of the extracts/n-butanol fraction of stem bark of $A$. catechu using HIV $_{\mathrm{NL4.3}}$ in TZM-bl cells based assay}

\begin{tabular}{llll}
\hline Treatment group & \multicolumn{3}{c}{ TZM-bl cells $(\boldsymbol{\mu g} / \mathbf{m l})$} \\
\cline { 2 - 4 } & ${ }^{*} \mathbf{C C}_{50}$ & ${ }^{*} \mathbf{C}_{\mathbf{5 0}}$ & TI \\
\hline 50\% Ethanolic extract & $371.0 \pm 11.7$ & $3.6 \pm 0.31$ & $103.0 \pm 6.3$ \\
Aqueous extract & $>400^{* *}$ & $1.8 \pm 0.18$ & $>200$ \\
n-Butanol fraction & $>400^{* *}$ & $1.7 \pm 0.12$ & $>200$
\end{tabular}

${ }^{*} \mathrm{CC}_{50}$ : The cytotoxic concentration of the extracts/ $n$-butanol fraction that caused the reduction of viable cells by $50 \%$. All data presented are averages of three independent experiments done in duplicates (mean \pm standard error).

${ }^{*} / C_{50}$ : The concentration of the extracts/n-butanol fraction that resulted in $50 \%$ inhibition in HIV-1 infection. All data presented are averages of three independent experiments done in duplicates (mean \pm standard error).

${ }^{* *} \mathrm{CC}_{50}$ was not obtained as there was no toxicity up to the maximum concentration tested.

TI: Therapeutic index is $\mathrm{CC}_{50} / \mathrm{IC}_{50}$. 


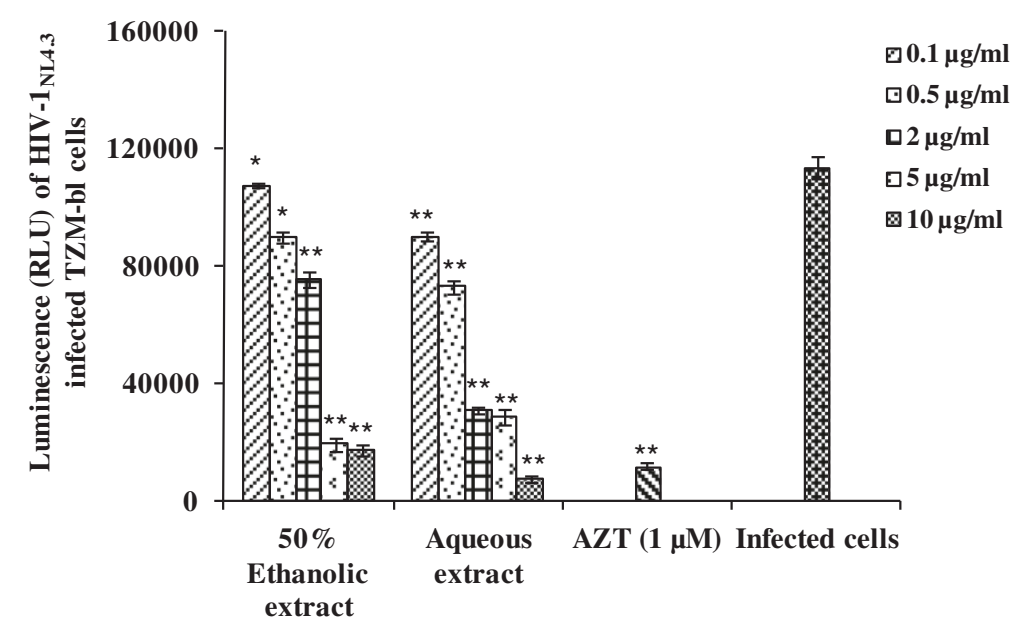

Figure 1 Anti-HIV-1 activity of Acacia catechu extracts. TZM-bl cells were infected with HIV-1 ${ }_{\text {NL4.3 }}(\mathrm{MOI}, 0.05)$ pretreated for $1 \mathrm{~h}$ with extracts prepared from A. catechu and incubated for $48 \mathrm{~h}$ in the presence or absence of extracts as described in Materials and Methods. Anti-HIV-1 activity at varying concentrations of the 50\% ethanolic, aqueous stem bark extracts and AZT $(1 \mu \mathrm{M})$, used as a positive reference control, has been shown. Y-axis represents the percent inhibition of HIV-1 infection. Values are expressed as mean \pm SE of 3 different experiments performed in duplicates. ${ }^{*} p<0.05 ;{ }^{* *} p<0.001$ (as compared to infected control group without any treatment).

inhibitory concentrations $\left(\mathrm{IC}_{50}\right)$ of the $50 \%$ ethanolic and aqueous extracts were $3.6 \pm 0.31$ and $1.8 \pm 0.18 \mu \mathrm{g} / \mathrm{ml}$, respectively (Table 1 ).

Of the three fractions, petroleum ether, chloroform and n-butanol soluble fractions prepared from the $50 \%$ ethanolic extract of stem bark, HPLC profiles suggest the chloroform fraction to be the most complex, with maximum number of peaks (Additional file 2: Figure S2). However, the n-butanol fraction demonstrated better cell viability and anti-HIV-1 activity. There was no toxicity observed by the n-butanol fraction up to a maximum concentration of $400 \mu \mathrm{g} / \mathrm{ml}$ on TZM-bl cells (Table 1). A dose-dependent inhibition was observed with an $\mathrm{IC}_{50}$ value of $1.7 \pm 0.12 \mu \mathrm{g} / \mathrm{ml}$ using TZM-bl cell based assay (Figure 2A; Table 1). Further, the n-butanol fraction exhibited a marked decrease in HIV- $1_{\mathrm{BaL}}$ (R-5 tropic) infection, at non-cytotoxic concentrations in TZM-bl cells (Figure 2B). The activity of n-butanol fraction was also evaluated against two primary isolates of CCR5-tropic HIV-1 (11IN1290SJ \& 17MT14), where potent inhibition was also observed against both the isolates (Figure 3). Further, to confirm the efficacy of the n-butanol fraction of $A$. catechu in primary cells, PHA-P activated human peripheral blood lymphocytes (PBLs) based assay was used. The n-butanol fraction $(100 \mu \mathrm{g} / \mathrm{ml})$ reduced the p24 concentration to $417 \mathrm{pg} / \mathrm{ml}$ as compared to $1525 \mathrm{pg} / \mathrm{ml}$ in control (infected PBLs without any treatment; Figure 4A) i.e. $73 \%$ inhibition in HIV-1 infection (Figure 4B). AntiHIV-1 activity of the n-butanol fraction in human PBLs was not due to non-specific cytotoxicity as more than $80 \%$ cells were viable when fraction was used at $100 \mu \mathrm{g} / \mathrm{ml}$ (Additional file 3: Figure S3). In an initial attempt, to isolate and characterize pure compounds responsible for anti-HIV-1 activity, five different compounds were purified and screened for their anti-HIV-1 activity using TZM-bl cells in cell-free virus based assay against HIV$1_{\text {NL4.3 }}$ (Table 2). Among these compounds, only catechins exhibited a potent anti-HIV-1 activity with $\mathrm{CC}_{50}$ and $\mathrm{IC}_{50}$ values of $950 \mu \mathrm{g} / \mathrm{ml}$ and $0.6 \mu \mathrm{g} / \mathrm{ml}$, respectively. Investigations for further identification of other anti-HIV-1 active compounds from the 50\% ethanolic extract of stem bark are under progress.

\section{Probable mechanism of action of the active fraction of A. catechu}

Further studies were performed to delineate the mechanisms by which the extracts/n-butanol fraction prepared from $A$. catechu inhibited HIV-1 infection. The inhibition by active n-butanol fraction against HIV-1 entry and inhibition of the HIV-1 enzymes; RT, integrase and protease were tested. The active fraction did not show any inhibition of HIV-1 $1_{\mathrm{NL} 4.3}$ entering into the host cells (TZM-bl) even at a dosage of $50 \mu \mathrm{g} / \mathrm{ml}$, when compared with the known entry inhibitor Bicyclam, which was 95\% effective even at $0.4 \mu \mathrm{g} / \mathrm{ml}$ (data not shown). In cell-based fusion assay that mimic the gp120-CD4mediated fusion [21], pre-treatment of HL2/3 cells (expressing HIV-1 Env on their surface and Tat protein in cytoplasm) with n-butanol fraction $(10 \mu \mathrm{g} / \mathrm{ml})$ did not lead to any significant inhibition in fusion with TZM-bl cells as determined by estimation of luciferase expression (Additional file 4: Figure S4a). We next determined whether the n-butanol fraction directly inhibited HIV-1 RT activity. Nevirapine $(1 \mu \mathrm{M})$, a potent RT inhibitor, inhibited HIV-1 RT activity by $72 \%$; however, n-butanol fraction did not show any effect on the RT activity 


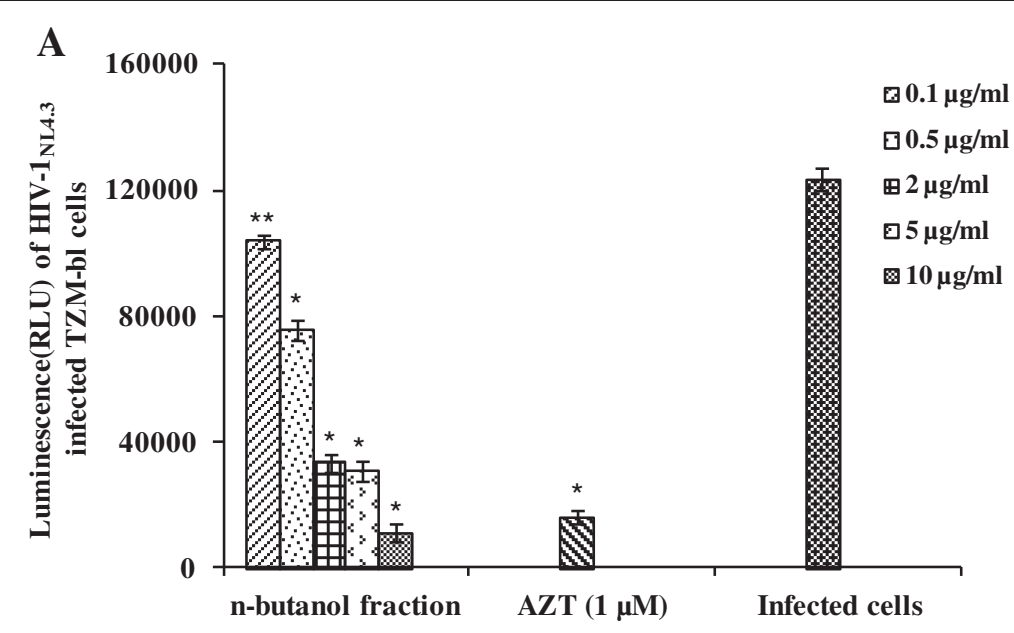

B

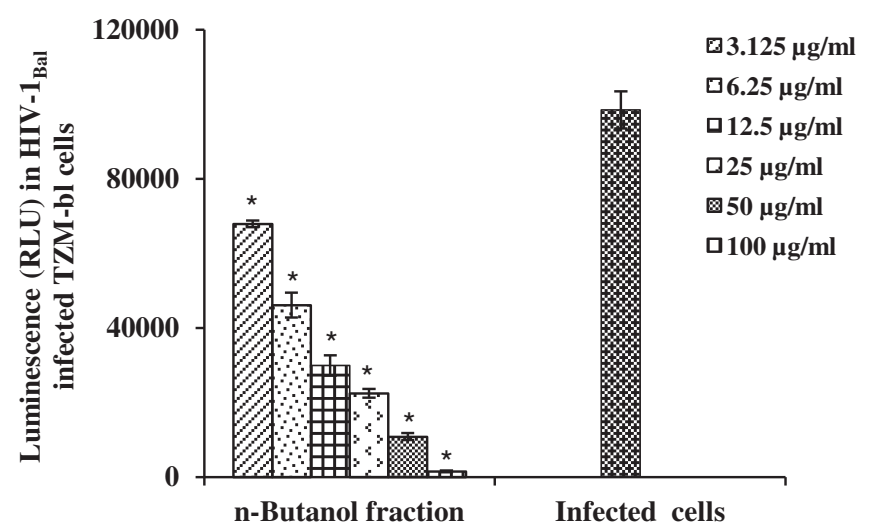

Figure 2 Anti-HIV-1 activity of $\mathbf{n}$-butanol fraction of Acacia catechu. A) Anti-HIV-1 $1_{\text {LL } 4.3}$ activity of n-butanol soluble fraction at different concentrations in TZM-bl cells. B) Inhibition against HIV-1 BaL infection using TZM-bl cells. Y-axis represents the luciferase expression in terms of relative luminescence unit (RLU) in HIV-1 infected and treated TZM-bl cells whereas X-axis represents different concentrations of the butanol fraction. Values are expressed as mean \pm SE of 3 different experiments performed in duplicates. ${ }^{*} p<0.05 ;{ }^{*} p<0.001$ (as compared to infected control group without any treatment).

(Additional file 4: Figure S4b). These results imply that inhibition of HIV-1 replication by the n-butanol fraction was not due to its effects on the RT activity but on other steps of HIV-1 life cycle. To evaluate the effect of n-butanol fraction on HIV-1 integrase, sodium azide $(0.1 \%)$ was used as a reference control that exhibited $>90 \%$ inhibition against HIV-1 integrase activity whereas the n-butanol fraction $(50 \mu \mathrm{g} / \mathrm{ml})$ did not show any significant inhibition of integrase activity (Additional file 4: Figure S4c). The lack of effect on viral integration was confirmed by treating TZM-bl cells infected with HIV$1_{\mathrm{NL4.3}}$, with either the $\mathrm{n}$-butanol fraction or vehicle control. Viral integration was monitored by Alu-LTR PCR (Figure 5). As compared to the positive reference control Raltegravir $(10 \mu \mathrm{M}$; a HIV-1 integrase inhibitor), there was no effect of the n-butanol fraction on the virus integration.
Finally, the effect of the n-butanol fraction was evaluated on HIV-1 protease activity. The n-butanol fraction showed a significant reduction in HIV-1 protease activity with an $\mathrm{IC}_{50}$ value of $12.9 \mu \mathrm{g} / \mathrm{ml}$ (Figure 6A). The standard HIV-1 protease inhibitor drug, Saquinavir $(1 \mu \mathrm{M})$ was used as a reference control that showed $100 \%$ inhibition. To validate the effect of active fraction on HIV-1 protease activity, release of mature viral particles by HIV-1 infected and extract treated PBLs was investigated. The culture supernatant was used to infect TZM-bl cells to quantify the infectivity of the released virions and hence correlate it with the HIV-1 protease activity. As compared with the culture supernatant obtained from untreated PBLs there was a decrease in the expression of luciferase when culture supernatant from PBL treated with n-butanol fraction was used (Figure 6B). Similar results were observed with the 


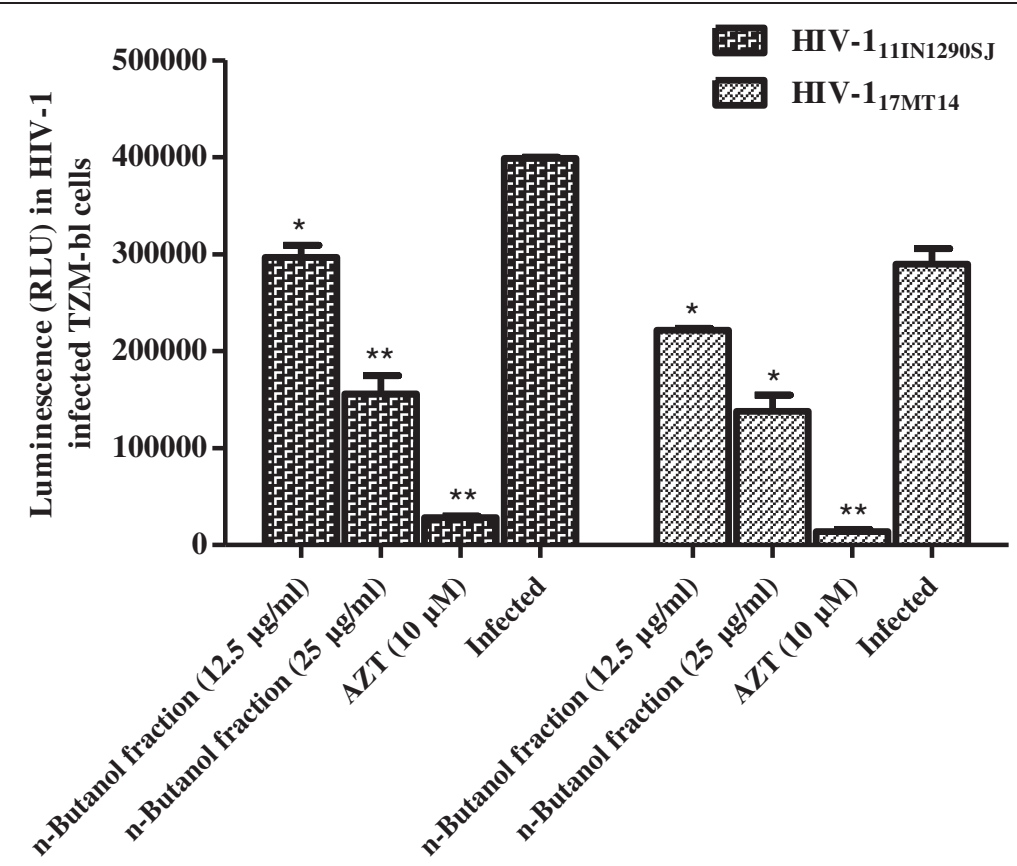

Figure 3 Anti-HIV-1 activity of $\mathbf{n}$-butanol fraction of Acacia catechu against CCR5-tropic clinical isolates. Anti-HIV-1 activity of n-butanol soluble fraction of $A$. catechu tested at two different concentrations/AZT $(10 \mu \mathrm{M})$ against clinical isolates namely HIV-1 $1_{111 \mathrm{~N} 12905}$ and HIV-1 ${ }_{17 \mathrm{MT} 14}$, Using TZM-bl cells. Y-axis represents the luciferase expression as RLU in HIV-1 infected and treated TZM-bl cells. Values are expressed as mean \pm SE of 3 different experiments performed in duplicate. ${ }^{*} p<0.05 ;{ }^{* *} p<0.01$ (as compared to infected control group without any treatment).

culture supernatant from HIV-1 infected PBL but treated with Saquinavir (Figure 6B).

To evaluate the inhibitory effect of extract/fraction on Tat mediated transactivation of HIV-1 gene expression, TZM-bl cells were transfected with pcDNA-Tat expression vector. In TZM-bl cells, luciferase reporter gene is under the control of LTR promoter and hence Tat-LTR mediated transactivation was determined by luciferase expression. The n-butanol fraction prepared from $A$. catechu stem bark showed a modest dose-dependent inhibition in luciferase expression (Figure 7A). Simultaneously, to see the reduction at mRNA level of luciferase gene (expression is under the control of Tat-LTR mediated activation), as a result of treatment of pcDNA-Tat transfected TZM-bl cells with n-butanol fraction, real-time PCR was performed as described in Materials and Methods. As expected, there was a dose dependent reduction in the level of luciferase mRNA in n-butanol fraction treated transfected cells when compared to untreated transfected cells (Figure 7B). Further in the Tat-EMSA, no bands were observed in Lane 1 (in presence of $50 \mu \mathrm{g} / \mathrm{ml}$ of n-butanol fraction) as compared to Lane 2 where bands appeared as a result of nuclear Tat protein interaction with DNA probe. These results demonstrated that the phytochemicals present in the stem bark n-butanol fraction interferes with the Tat-LTR interaction mediated transactivation of viral genes in addition to $\mathrm{HIV}-1$ protease activity (Figure 7C).
Preclinical safety study of $\mathrm{n}$-butanol fraction of $A$. catechu As an attempt to evaluate the toxic effect of extracts/fraction on vaginal keratinocytes $\mathrm{Vk2/E6E7,} \mathrm{MTT} \mathrm{assay} \mathrm{was}$ used. No cytotoxicity was observed up to $100 \mu \mathrm{g} / \mathrm{ml}$, by the extracts and the $\mathrm{n}$-butanol fraction prepared from A. catechu (data not shown). Further to assess the adverse effect of these extracts/fraction on pro-inflammatory cytokine secretion, compared to the control, both the plant extracts as well as n-butanol fraction at $100 \mu \mathrm{g} / \mathrm{ml}$ did not lead to any increase in the secretion of IL-8. However, a substantial decrease in its secretion was observed by $50 \%$ ethanolic extract and n-butanol fraction of $A$. catechu (Table 3). A decreased secretion of IL-6 was also observed in case of cells treated with $50 \%$ ethanolic stem bark extract $(34.8 \mathrm{pg} / \mathrm{ml})$ and its n-butanol fraction $(8.8 \mathrm{pg} / \mathrm{ml})$ as compared to control value $(118.0 \mathrm{pg} / \mathrm{ml}$; Table 3$)$. However, no change in the secretion of IL- $1 \beta$ and TNF by vaginal keratinocytes was observed with any of the treatment group at $100 \mu \mathrm{g} / \mathrm{ml}$ (Table 3 ).

Measurement of transepithelial resistance (TER) has been done on the tight junctions formed by epithelial cells such as Caco-2, HEC-1A and MDCK-1 [22]. Nonoxynol-9 (N-9) originally developed as a spermicidal, with activity against sexually transmitted pathogens including HIV-1 led to epithelial disruption as well as toxicity to the rectal mucosa as reported by different studies, and hence was included as a positive control in this work [23]. The n-butanol fraction of $A$. catechu was non-toxic on both 

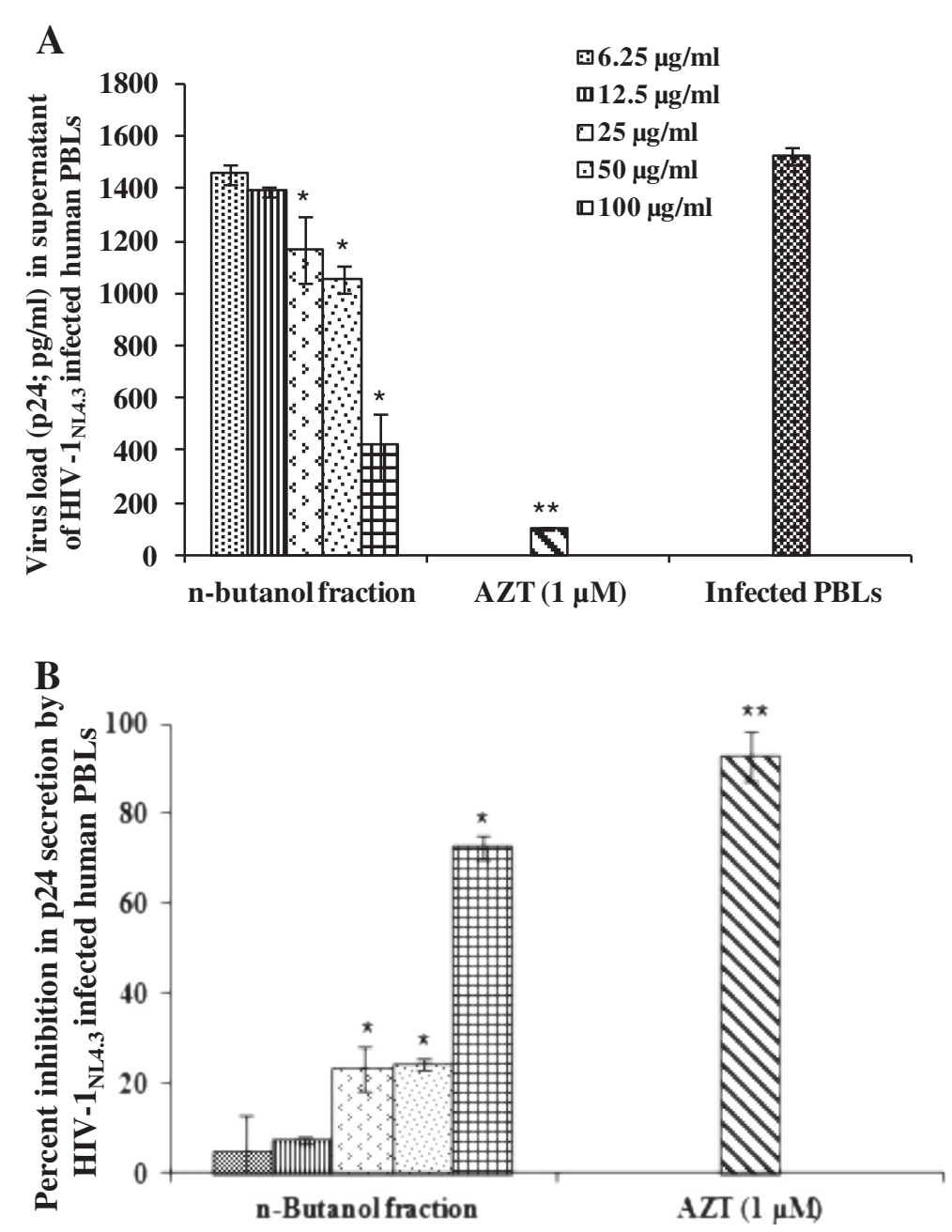

Figure 4 Anti-HIV-1 activity of $n$-butanol fraction of Acacia catechu using human peripheral blood lymphocytes (PBLs). A) Anti-viral

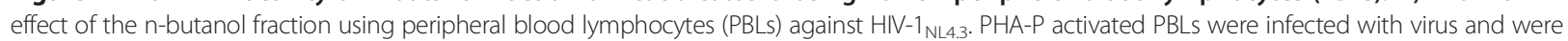
treated with different concentration of n-butanol fraction from A. catechu. p24 was estimated on $5^{\text {th }}$ day in the culture supernatant. Significance (p-value) was calculated by comparison with amount of p24 in the infected control group. B) The amount of p24 secreted by infected PBLs in term of percent inhibition presented on the $\mathrm{Y}$-axis. Values are expressed as mean $\pm \mathrm{SE}$ of 3 different experiments. ${ }^{*} \mathrm{p}<0.05$; ${ }^{* *} \mathrm{p}<0.001$ (as compared to infected control group without any treatment).

Caco-2 and HEC-1A cells when tested up to $100 \mu \mathrm{g} / \mathrm{ml}$ (data not shown). After application of the n-butanol fraction to the apical monolayer of Caco-2 cells (Figure 8A) and HEC-1A cells (Figure 8B), there was no measurable effect on TER as shown by the consistency of the treated monolayer as compared to the untreated control.

\section{Discussion}

A. catechu is commonly known as Mimosa catechu, whose phytoconstituents possess several pharmacological properties $[15,18,24,25]$. A. catechu, a medicinally and economically important plant, may serve as novel source of anti-HIV-1 active compounds. Although, anti-HIV-1 activity has been reported previously from different species of the genus Acacia e.g. Acacia confusa [26], no such activity has been shown from $A$. catechu. Our interest was to systematically evaluate aqueous and alcohol extracts of A. catechu for activity against HIV-1. Both the extracts exhibited a dose-dependent inhibition of HIV-1 infection at concentrations ranging from $0.1-10 \mu \mathrm{g} / \mathrm{ml}$ against HIV$1_{\text {NL4.3. }}$. Therapeutic indices (TI) of the $50 \%$ ethanolic and aqueous extracts prepared from stem bark were calculated as the ratio of $\mathrm{CC}_{50}$ to $\mathrm{IC}_{50}$. A TI of $>100$ by these extracts suggest the plant as a candidate for further evaluation (Table 1). Further, $50 \%$ ethanolic extract was partitioned to yield petroleum ether, chloroform and n-butanol soluble fractions. Out of the three fractions, the n-butanol fraction demonstrated better anti-HIV-1 potential. Further, the n-butanol fraction exhibited a marked decrease in HIV-1 infection by HIV-1 $1_{\mathrm{BaL}}$ (R-5 tropic) as well as 
Table 2 Different compounds isolated from $\mathbf{5 0 \%}$ ethanolic stem bark extract of Acacia catechu

\begin{tabular}{|c|c|c|c|}
\hline Compounds & $\begin{array}{l}\text { Anti-HIV-1 } \\
\text { activity }\end{array}$ & $\begin{array}{l}\text { Physical } \\
\text { aspect }\end{array}$ & Chemical Family \\
\hline \multirow[t]{2}{*}{ Catechins } & $C C_{50}=950 \mu \mathrm{g} / \mathrm{ml}$ & \multirow[t]{2}{*}{ White powder } & \multirow{2}{*}{$\begin{array}{l}\text { Flavonoids; } \\
\text { (+)-catechin; \& (-)- } \\
\text { epicatechin (cis) }\end{array}$} \\
\hline & $\mid C_{50}=0.60 \mu \mathrm{g} / \mathrm{ml}$ & & \\
\hline Kaempferol & No & $\begin{array}{l}\text { Yellow } \\
\text { crystalline } \\
\text { powder }\end{array}$ & Flavonoid \\
\hline Rutin & No & $\begin{array}{l}\text { Yellow } \\
\text { powder }\end{array}$ & $\begin{array}{l}\text { Flavonoid } \\
\text { glycoside }\end{array}$ \\
\hline Ferulic acid & No & $\begin{array}{l}\text { Yellow-white } \\
\text { crystalline } \\
\text { powder }\end{array}$ & Polyphenol \\
\hline Caeffic acid & No & $\begin{array}{l}\text { Yellow } \\
\text { powder }\end{array}$ & Polyphenol \\
\hline
\end{tabular}

displayed a potent inhibition of infection of primary isolates of CCR5-tropic HIV-1 at non-cytotoxic concentrations. In an attempt to identify the active compounds from stem bark of $A$. catechu responsible for anti-HIV-1 activity, a total of 6 compounds from 50\% ethanolic extract, were isolated and characterized using different chromatographic and spectroscopic studies (Table 2). Different compounds like catechins, kaempferol, rutin, ferulic acid and caeffic acid have been isolated and characterized from $A$. catechu, among which catechins have shown a very potent anti-HIV-1 activity in its preliminary studies. Other compounds, however failed to inhibit HIV-1 infection in cell-free virus based assay (data not shown). In previous studies, catechins, epicatechin, epicatechin-3-Ogallate and epigallocatechin-3-O-gallate were reported as the predominant compounds present in A. catechu [27].
In different investigations by several other groups, catechins isolated from tea leaves have been reported to inhibit HIV-1 infection [28,29].

In an attempt, to explore the mode of inhibition of HIV-1 infection by the active fraction of $A$. catechu, different in vitro assays were performed. The n-butanol fraction failed to inhibit the viral entry to the host cells. Due to the essential role of HIV-1 RT in synthesizing the double-stranded proviral DNA from single-stranded HIV-1 RNA genome, it is a major target among the current anti-HIV-1 therapies. The n-butanol fraction did not exhibit inhibitory activity against RT enzyme. Further, the activity of the n-butanol fraction was assessed against HIV-1 integrase, an enzyme that leads to the integration of the reverse transcribed viral DNA into the genome of the cell and hence plays an essential role in HIV-1 replication. The n-butanol fraction showed no adverse effect on this enzyme activity. Suppression of HIV-1 infection by n-butanol fraction was not at the pre-integration or integration steps, which was confirmed by Alu-LTR PCR where the active extract did not inhibit integration of viral genome into host DNA. Hence, the inhibitory effect of $n$-butanol fraction may be at the post-integration stage.

HIV-1 protease, an aspartyl protease, is another crucial enzyme essential for the life cycle of HIV-1, as it cleaves newly synthesized poly-proteins to create the mature protein components of an infectious HIV-1 virion. Protease inhibitors bind to the active site of the viral protease enzyme, preventing the processing of viral particles into mature and functional form. Interestingly, the n-butanol fraction of $A$. catechu showed a potent inhibition of HIV-1 protease activity. This finding was further supported by

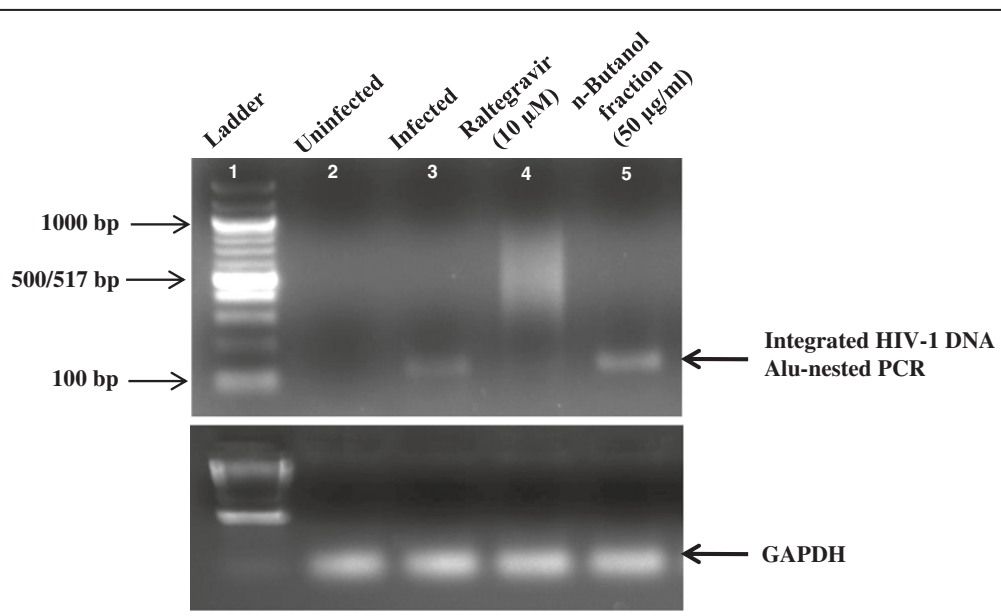

Figure 5 Effect of $\mathbf{n}$-butanol fraction prepared from A. catechu on integration of HIV-1 genome in host cells. TZM-bl cells were infected with HIV-1 ${ }_{\mathrm{NL} 4.3}(\mathrm{MOI}, 0.05)$ pretreated for $1 \mathrm{~h}$ with $\mathrm{n}$-butanol fraction prepared from A. catechu $(50 \mu \mathrm{g} / \mathrm{ml})$ and Raltegravir $(10 \mu \mathrm{M})$, used as a positive reference control and incubated for $48 \mathrm{~h}$ in the presence or absence of extract/Raltegravir as described in Materials and Methods. After 48 h, cells were trypsinized and washed. Genomic DNA was isolated from HIV-uninfected/infected cells. DNA (200 ng) was used as a template and viral integration was monitored by Alu-LTR-PCR with Alu-gag primers and GAPDH was used as internal control. 


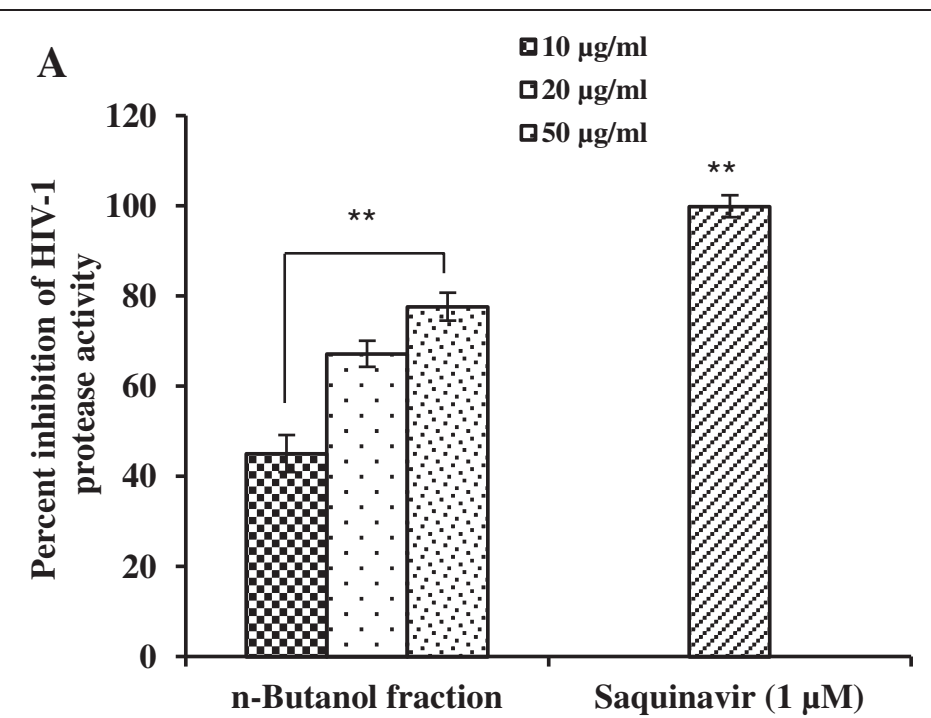

\section{B}

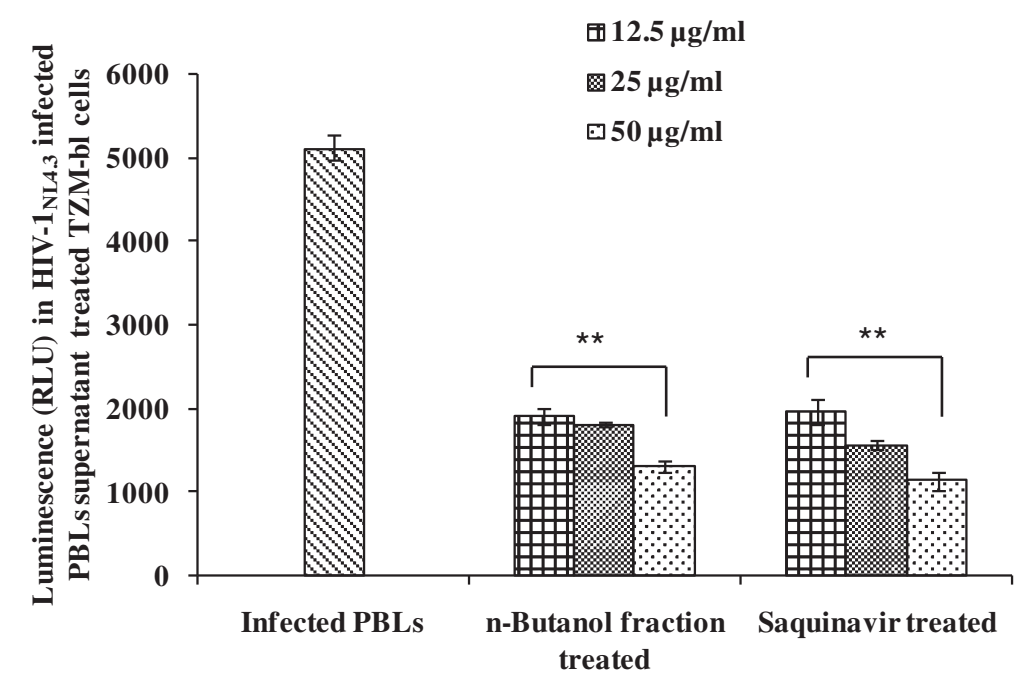

TZM-bl cells infected with supernatant secreted by PBLs

Figure 6 Effect of $\mathrm{n}$-butanol fraction of $A$. catechu on HIV-1 protease activity and maturation of virion particles. A) Dose dependent inhibition in HIV-1 protease activity by the $\mathrm{n}$-butanol fraction as compared with Saquinavir used as a reference control in a commercial ELISA kit. ${ }^{* *} p<0.01$ (as compared to enzyme only control). B) Comparison of the infectivity of TZM-bl cells by the virions released from the infected and n-butanol fraction/Saquinavir (a protease inhibitor) treated PBLs. The culture supernatant collected on $5^{\text {th }}$ day was used to infect TZM-bl cells for 48 hours and relative luminescence unit (RLU) was calculated by lysing the cells as described in Materials and Methods. Y-axis represents the luciferase expression as RLU. Values are expressed as mean \pm SE of 2 different experiments performed in duplicate. ${ }^{* *} p<0.01$ (as compared to cells treated with soup from infected control group without any treatment).

the observations that there was a decrease in the release of mature viral particles by infected PBLs after treatment with the n-butanol fraction as shown by reduction of greater than $50 \%$ infectious virus in the TZM-bl assay. Catechins containing galloyl moieties from different plant sources have been reported to target several key proteins of HIV-1. Hence, they may inhibit sexual transmission of HIV-1 by interfering with HIV-1 protease activities [30].

Viral Tat protein plays a pivotal role in both the HIV-1 replication cycle and the pathogenesis of HIV-1 infection
[31-33]. HIV-1 Tat protein transactivate HIV-1 LTR promoter by binding to the nascent RNA stem-loop structure known as the transactivator response region (TAR). It has also been shown to bind to NFkB enhancer sequence [33]. Hence, inhibiting Tat-mediated functions could be another critical step of intervention by $A$. catechu. Transfection of TZM-bl cells with pTat expression vector wherein luciferase expression is under the control Tat-LTR mediated activation, followed by n-butanol fraction treatment resulted in dose-dependent suppression of luciferase 

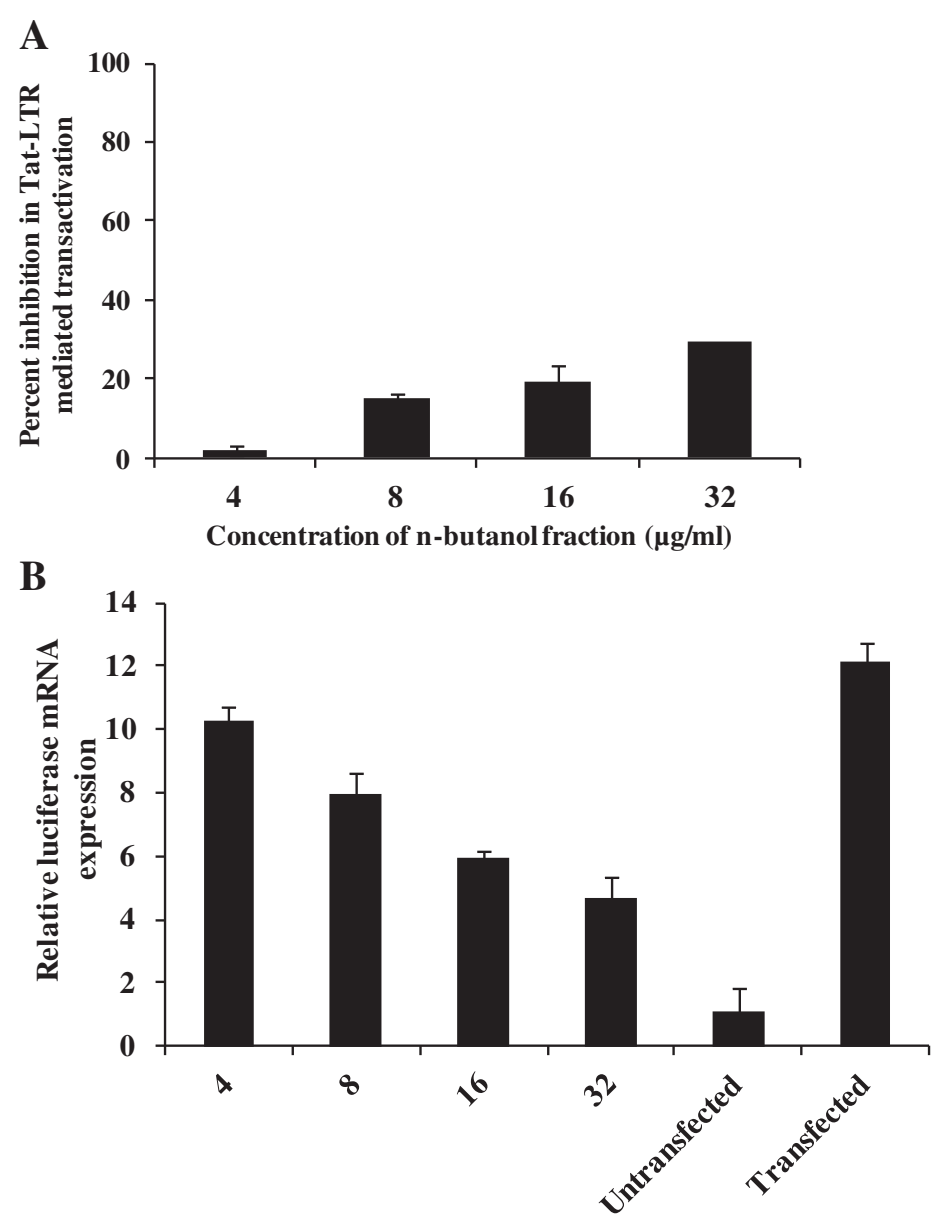

Concentration of n-butanol fraction $(\mu \mathrm{g} / \mathrm{ml})$

C

$\begin{array}{llll}1 & 2 & 3 & 4\end{array}$

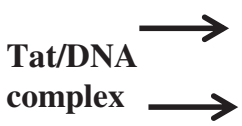

n-Butanol fraction $(50 \mu \mathrm{g} / \mathrm{ml})$

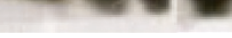

Tat TF-DNA probe $\quad++++$

Cold Tat TF-DNA Probe $\quad-\quad+\quad+$

Figure 7 (See legend on next page.) 
(See figure on previous page.)

Figure 7 Study of mechanism of action of the $\mathbf{n}$-butanol fraction of Acacia catechu. A) Inhibitory activity of n-butanol fraction against Tat-mediated HIV-1 genes transactivation by pTat transfection in TZM-bl cells. Values are expressed as average of 2 different experiments performed in duplicates. B) The effect of $n$-butanol fraction on luciferase gene expression at mRNA level. The $n$-butanol fraction prepared from $50 \%$ ethanolic extract of stem bark of $A$. catechu was added to TZM-bl cells post-transfection with pTat. Reduction in the expression of luciferase gene was validated by qRT-PCR. qRT-PCR data is expressed as fold change in expression as compared to control. Values are expressed as mean \pm SE of 2 different experiments performed in duplicate. C) The inhibitory activity of $n$-butanol fraction using Tat based Electrophoretic Mobility Shift Assay (EMSA). Tat protein was incubated with DNA probe in presence or absence of the active n-butanol fraction of the plant. Samples were run in $6 \%$ non-denaturing polyacrylamide gel. Lane 1 is with Tat transcription factor (TF) DNA probe + Tat protein (nuclear extract prepared from transfected TZM-bl cells) + n-butanol fraction $(50 \mathrm{\mu g} / \mathrm{ml})$; Lane 2, TF DNA probe + Tat protein; Lane 3, TF DNA probe only; Lane 4 - TF DNA probe + Cold TF DNA

probe + Tat protein.

expression. This observation was further corroborated by the expression level of luciferase mRNA using qRT-PCR. The inhibition of Tat and LTR interaction was also confirmed by the Tat-EMSA experiment. Several plantderived compounds such as quinolines as well as stilbeneand purine-derivatives have been reported before to illustrate anti-HIV-1 activity by inhibiting Tat-LTR interactions [31]. Our unpredicted finding that $A$. catechu stem bark has a dual inhibitory mechanism demonstrates that herbal drugs can be developed that simultaneously inhibits HIV-1 protease as well as Tat-LTR mediated HIV-1 transcription.

The effect of these extracts/n-butanol fractions on vaginal keratinocytes viability is highly relevant, if the active fraction is considered as a topical agent that may be applied for prevention of HIV-1 transmission (microbicides), as vaginal epithelial cells form part of the physical barrier that may impede the passage of cell-free or cell-associated HIV-1 into sub-epithelial tissues. An effective vaginal microbicide should also obviate pro-inflammatory responses that facilitate transepithelial viral penetration and its replication. Pro-inflammatory cytokines such as IL-1 $\beta$, IL-6, IL-8 and TNF stimulate viral replication in latently infected cells and hence may constitute a considerable inducible HIV-1 reservoir in the genital secretions [34]. Therefore, it was important to rule out induction of inflammatory cytokines secretion after application of the plant extracts/n-butanol fraction on vaginal keratinocytes.

Table 3 Pro-inflammatory cytokines secretion by vaginal keratinocytes after treatment for $\mathbf{2 4} \mathrm{h}$ with extracts/ $\mathrm{n}$-butanol fraction prepared from stem bark of $\boldsymbol{A}$. catechu

\begin{tabular}{lllll}
\hline \multirow{2}{*}{$\begin{array}{l}\text { Treatment with } \\
\text { llant extract/fraction* }\end{array}$} & \multicolumn{4}{c}{ Level of cytokines (pg/ml) } \\
\cline { 2 - 5 } & IL-8 & IL-1 $\beta$ & IL-6 & TNF \\
\hline Control & $\mathbf{2 8 2} \pm \mathbf{5 . 3}$ & $\mathbf{2 . 2} \pm \mathbf{0 . 2}$ & $\mathbf{1 1 8} \pm \mathbf{9 . 1}$ & $\mathbf{1 . 1} \pm \mathbf{0 . 6}$ \\
Aqueous extract & $248 \pm 11.1$ & $3.4 \pm 0.2$ & $115.0 \pm 8.4$ & $1.7 \pm 0.1$ \\
50\% Ethanolic extract & $40.4 \pm 3.9^{* *}$ & $4.0 \pm 0.0$ & $34.8 \pm 1.3 \#$ & $1.7 \pm 0.3$ \\
n-Butanol fraction & $2.7 \pm 0.6^{* *}$ & $3.4 \pm 0.3$ & $8.8 \pm 0.6 \#$ & $1.8 \pm 0.5$ \\
\hline
\end{tabular}

*Various plant extracts $/ \mathrm{n}$-butanol fraction were used at $100 \mathrm{\mu g} / \mathrm{ml}$.

${ }^{* *} p<0.001$ as compared to IL-8 concentration in the control group.

$\# p<0.001$ as compared to IL-6 concentration in the control group.
There was no cytotoxicity observed by all the extracts/ fraction up to $100 \mu \mathrm{g} / \mathrm{ml}$ and none of them led to a significantly enhanced secretion of pro-inflammatory cytokines as an effect to VK2/E6E7 cells treatment. Since both IL-6 and IL-8 are associated with an increased HIV-1 replication, this could be an added advantage of the active n-butanol fraction of $A$. catechu as an anti-HIV-1 microbicide $[35,36]$. The decrease in secretion of proinflammatory cytokines, IL-6 as well as IL-8, may be due to the catechins that are present in abundance in the stem bark of $A$. catechu and have been reported previously for their anti-inflammatory properties [15]. Preclinical safety investigations should also comprise evaluation of interference with epithelial integrity. Maintenance of an intact as well as polarized monolayer in presence of a potential microbicide candidate is an important factor to be considered as any damage in epithelial layer may allow infectious virus to reach the host target cells [22,23]. Observed transient decrease in TER of $\mathrm{CaCo}-2$ cells in presence of $n$-butanol fraction, may be due to the differential sensitivity of CaCo-2 cells versus HEC-1A cells as shown previously with tenofovir gel [37]. With no deleterious effect on the epithelial barrier layer, the extracts as well as n-butanol fraction from A. catechu appears to be safe and suggests their utility as microbicide candidate.

\section{Materials and methods \\ Collection of plant material}

A. catechu plant material was collected three times from Balrampur, Uttar Pradesh, India. The voucher specimen (accession number NBRH-04) has been submitted to Herbarium of National Botanical Research Institute, Lucknow, India.

\section{Extraction and solvent fractionation of plant material}

Air and shed dried stem bark from A. catechu was grinded and strained through 30 mesh $(0.5 \mathrm{~mm})$. The finely grinded stem bark $(100 \mathrm{gm})$ was treated with $500 \mathrm{ml}$ MilliQ water at $60-75^{\circ} \mathrm{C}$ for $6-8 \mathrm{~h}$. This process was repeated three more times. The hot water extract was filtered through Whatman filter paper number 1 . The 


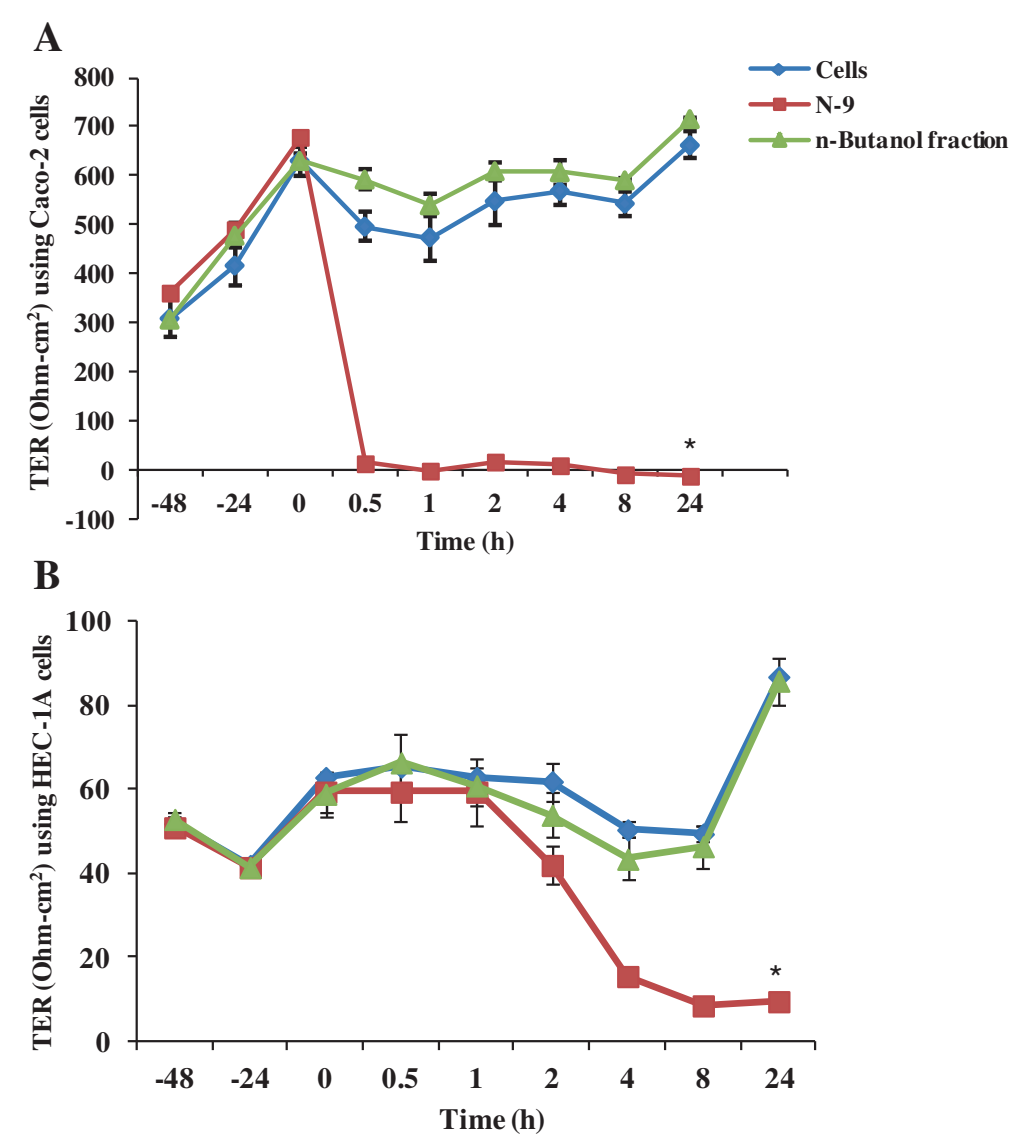

Figure 8 Effect of $n$-butanol fraction of Acacia catechu on transepithelial resistance on monolayer of epithelial cells. A) The effect of n-butanol fraction on Caco-2 epithelial cells monolayer integrity. Plant n-butanol fraction/Nonoxynol-9 (N-9) was added to the apical chamber at $\mathrm{t}=0$ and transepithelial resistance (TER) readings were measured at 0.5, 1, 2, 4, 8 and $24 \mathrm{~h}$. As toxicity control, N-9 gel (1:50 dilution $\sim 0.6 \mathrm{mg} / \mathrm{ml})$ was added to the indicated well. B) The effect of the $n$-butanol fraction on TER of HEC-1A cells. Values are expressed as mean \pm SE of 2 different experiments performed in duplicates.

combined filtrate $(1300 \mathrm{ml})$ was distilled at $45-50^{\circ} \mathrm{C}$ under vacuum to concentrate the extract to $300 \mathrm{ml}$. The extract was then lyophilized at -20 to $-40^{\circ} \mathrm{C}$ to afford $7-9 \%$ dry extract. To prepare 50\% ethanolic extract, finely grinded plant material (100 gm) was charged in a percolator and treated with ethanol: water $(1: 1 \mathrm{v} / \mathrm{v} ; 500 \mathrm{ml})$ at $25-30^{\circ} \mathrm{C}$ overnight. The marc was extracted thrice by cold percolation $(1: 1 \mathrm{v} / \mathrm{v} ; 500 \mathrm{ml} \times 3)$ and the combined percolate $(1000 \mathrm{ml})$ was evaporated at $40-45^{\circ} \mathrm{C}$ under vacuum to obtain $7-9 \%$ dry extract. The dried $50 \%$ ethanolic stem bark extract $(10 \mathrm{gm})$ was suspended in $100 \mathrm{ml}$ petroleum ether, followed by stirring at $10-20 \mathrm{rpm}$ at $30-40^{\circ} \mathrm{C}$ for 30-60 min and was subsequently left overnight at room temperature $\left(25-30^{\circ} \mathrm{C}\right)$. Petroleum ether soluble fraction was collected after filtration. The marc (residual petroleum ether insoluble extract) was treated three more times with the petroleum ether as above, to collect the total petroleum ether soluble fraction. It was concentrated at $30-40^{\circ} \mathrm{C}$ and finally dried under vacuum to collect $7-9 \%$ of dried petroleum ether soluble fraction. The residual petroleum ether insoluble extract, left after extraction, was air dried for 20-30 h. It was then suspended in $100 \mathrm{ml}$ of chloroform followed by stirring at $10-20 \mathrm{rpm}$ at $30-40^{\circ} \mathrm{C}$ for 30-60 min and was left overnight at room temperature. The clear chloroform soluble fraction was collected after filtration through Whatman filter paper number 1 . The residual chloroform insoluble extract was treated thrice with the chloroform as above, to collect the total chloroform soluble fraction. It was concentrated at $35-45^{\circ} \mathrm{C}$ and finally vacuum dried to collect $17-20 \%$ of dried chloroform soluble fraction. The residual chloroform insoluble extract was air dried for $20-30 \mathrm{~h}$ and treated in a similar way with $\mathrm{n}$-butanol to prepare the n-butanol soluble fraction.

\section{Isolation of compounds}

The $50 \%$ ethanolic extract $(10 \mathrm{~g})$ from stem bark was chromatographed on silica gel (100-200 mesh, Merck, Darmstadt, Germany) using petroleum ether, ethyl acetate and methanol as eluants. The ethyl acetate and methanol 
soluble fractions (95:5 to 80:20 v/v) afforded 5 compounds, which were further purified by preparative Thin Layer Chromatography (TLC) using different solvents. These compounds were identified by direct comparison with the spectroscopic data (NMR and MS) of authentic samples, procured from MP Biomedicals, Ohio, Solon, USA; Life Biochem Technologies Pvt. Ltd., New Delhi, India and Sigma Aldrich Inc., St Louis, MO, USA.

\section{Cells}

TZM-bl cells [HeLa cell line expressing high levels of CD4, HIV-1 co-receptors CCR5 \& CXCR4 with $\beta$ galactosidase and luciferase as reporter genes under HIV-1 LTR promoter; 38], HEC-1A [American Type Culture Collection, Manassas, VA, USA; an endometrial adenocarcinoma cell line; 39] and HEK-293 T cells were maintained in Dulbecco's modified Eagle's medium (DMEM; Sigma-Aldrich Inc.) supplemented with 10\% fetal bovine serum (FBS; Biological Industries, Kibbutz beitHaemek, Israel) and an antibiotic-antimycotic cocktail [Penicillin (100 units/ml), Streptomycin $(100 \mu \mathrm{g} / \mathrm{ml})$ and Amphotericin B (250 ng/ml); Pen-Strep-Ampho sol, Biological Industries]. Peripheral blood lymphocytes (PBLs; obtained through IRB-approved protocol) and Caco-2 cells (American Type Culture Collection; a human epithelial colorectal adenocarcinoma cell line) were cultured in RPMI supplemented with 10\% FBS and antibiotic-antimycotic cocktail as mentioned above. An immortalized cell line, Vk2/E6E7 (derived from the normal human vaginal mucosa), a generous gift from Dr. Raina Fichorova (Brigham and Women's Hospital, Boston, MA, USA) was cultured in Keratinocyte serumfree medium (ker-sfm; Gibco- Invitrogen, Carlsbad, CA, USA) supplemented with bovine pituitary extract and epidermal growth factor [EGF; Gibco-Invitrogen; 40].

\section{Virus generation}

HIV- $1_{\text {NL4.3 }}$ (CXCR4 tropic virus) was prepared by transfecting HEK-293 T cells with proviral plasmid DNA clone pNL4.3 (AIDS Research and Reference Reagent Program [ARRRP], Division of AIDS, National Institute of Allergy and Infectious Diseases, USA) using $\mathrm{CaPO}_{4}$. The medium was changed $24 \mathrm{~h}$ post-transfection and the supernatant was harvested after $48 \mathrm{~h}$ of incubation and frozen at $-80^{\circ} \mathrm{C}$. The concentration of virus stock was determined by the HIV-1 p24 Antigen Capture Assay ELISA (SAIC-Frederick Inc., NCI-Frederick, USA) and by determining the infectious titer using TZM-bl cells. Known inhibitors against HIV-1 infection, Azidothymidine (AZT; reverse transcriptase inhibitor; SigmaAldrich Inc.), Saquinavir (a protease inhibitor; ARRRP), Nevirapine (RT inhibitor; ARRRP) and Bicyclam (CXCR4 fusion inhibitor; ARRRP) were used as experimental controls.

\section{Anti-HIV-1 activity study}

\section{Cell-free virus based assay using TZM-bl cells}

TZM-bl cells $\left(4.0 \times 10^{4} /\right.$ well $)$ were seeded in 24 -well plate and cultured overnight. In separate vials, HIV-1 $1_{\mathrm{NL} 4.3}$ at a multiplicity of infection (MOI) of 0.05 whereas $\mathrm{HIV}-1_{\mathrm{BaL}}$ at $\mathrm{TCID}_{50}$, were treated with extracts/fractions or solvents used to prepare above extracts/fractions for $1 \mathrm{~h}$ at $37^{\circ} \mathrm{C}$. Subsequently, pretreated viruses were added in duplicate to TZM-bl cells and cultured for $4 \mathrm{~h}$. The cells were washed once with cold $50 \mathrm{mM}$ PBS, $\mathrm{pH}-7.4$ to remove the cell-free virus followed by addition of fresh culture medium with extracts/fractions and further incubated for $48 \mathrm{~h}$ in humidified atmosphere of $5 \mathrm{CO}_{2}$ at $37^{\circ} \mathrm{C}$. $\mathrm{AZT}$ was used as a positive reference control whereas negative control comprised of cells without HIV-1 infection. After incubation, cells were washed twice with PBS and lysed with 1X lysis buffer (Promega Corporation, Madison, USA) by freeze-thaw. The supernatant was analyzed for luciferase activity by BrightGlo Luciferase Assay kit (Promega Corporation) in white opti-plate and luminescence was read using Fluorimeter (BMG Labtech $\mathrm{GmbH}$, Offenberg, Germany) at a spectral range of 240-740 nm. The n-butanol fraction prepared from $A$. catechu was also evaluated for its efficacy against CCR5-tropic clinical isolates using the same protocol except that the culture medium in addition contain DEAE-dextran hydrochloride (50 $\mathrm{gg} / \mathrm{ml}$, Sigma-Aldrich Inc).

\section{Cell-associated virus based assay using peripheral blood lymphocytes (PBLs)}

Experiments using human blood cells were carried out under informed consent and following the clearance from the Institutional Bio-safety and Human Ethical Committee. Blood (5 ml) was taken from healthy HIV-1 seronegative donors and lymphocytes were isolated using Ficoll density gradient method. Cells $\left(2.0 \times 10^{6}\right.$ cells $/ \mathrm{ml}$ ) were stimulated with phytohemagglutinin (PHA-P; Sigma-Aldrich Inc.) at $3 \mu \mathrm{g} / \mathrm{ml}$ for 3 days. After stimulation, cells were washed twice with PBS. PBLs were infected with $\mathrm{HIV}-1_{\mathrm{NL} 4.3}$ at an MOI of 0.05 , in presence of IL-2 $(10 \mathrm{U} / \mathrm{ml})$ for $4 \mathrm{~h}$. Cells were washed twice with plain medium to remove the unbound virus and seeded in 96-well plate $\left(5.0 \times 10^{4} /\right.$ well $\left./ 200 \mu \mathrm{l}\right)$ in RPMI medium supplemented with $10 \%$ FBS and recombinant human IL-2 $(10 \mathrm{U} / \mathrm{ml})$. Plate was further incubated at $37^{\circ} \mathrm{C}, 5 \% \mathrm{CO}_{2}$ after adding the n-butanol fraction at varying concentrations to the wells. Cell culture supernatant was collected on $5^{\text {th }}$ day for p24 analysis. The culture supernatant $(100 \mu \mathrm{l})$ was further used for infection of TZM-bl cells for $4 \mathrm{~h}$, and luciferase expression was estimated after $48 \mathrm{~h}$ as described above to validate the infectivity of virion particles released by PBLs as an effect of treatment with n-butanol fraction of $A$. catechu. 


\section{p24 ELISA}

Virus in the culture supernatant of n-butanol fraction/ AZT treated human PBLs was quantitated by p24 estimation using an ELISA kit (SAIC-Frederick Inc., NCI-Frederick, USA; XpressBio, Life Science Products, $\mathrm{MD}$, USA), following the instructions of the manufacturer. Virus load in uninfected cells was used as negative control whereas virus load in solvent treated infected cells was the virus control. Test control includes virus load in infected PBLs treated with either n-butanol fraction/AZT.

\section{Study of mechanism of inhibition of HIV-1 infection HIV-1 entry assay}

TZM-bl cells $\left(4 \times 10^{4}\right)$ were pretreated with or without plant n-butanol fraction at $37^{\circ} \mathrm{C}$ for $1 \mathrm{~h}$ before being infected at an MOI of 0.05. Bicyclam was used as a reference control. The infected cells were trypsinized and washed with PBS to remove the unattached virus and cultured in fresh medium. After $48 \mathrm{~h}$ incubation, percent inhibition in HIV-1 infection was determined as described.

\section{Env-dependent fusion assay}

This bioassay allows testing for inhibitors capable of interfering with the CD4-Env interaction [41]. It employs HL2/3 cell line that express Gag, Env, Tat, Rev, and Nef, but not reverse transcriptase and secretes the env protein in the medium. HL2/3 cells $\left(2.5 \times 10^{4}\right)$ were treated with the butanol fraction $(25 \mu \mathrm{g} / \mathrm{ml})$ in separate vials for $30 \mathrm{~min}$ and washed thereafter. Pretreated HL2/3 cells were then incubated with untreated TZM-bl cells $\left(2.5 \times 10^{4}\right)$ for another $30 \mathrm{~min}$. Cells were then seeded in a 24-well plate $\left(2.5 \times 10^{4}\right.$ of each cell type/well) and incubated at $37^{\circ} \mathrm{C}$ in $5 \% \mathrm{CO}_{2}$. Fusion was readily detected microscopically after $8 \mathrm{~h}$ incubation. As a result of fusion, the luciferase as well as $\beta$-galactosidase gene under the LTR promoter gets expressed in the reporter TZM-bl cells. For quantitation of luciferase expression, the cells were harvested after 36 to $48 \mathrm{~h}$, lysed in $100 \mu \mathrm{l}$ of $1 \mathrm{X}$ lysis buffer and luciferase activity was estimated as described above.

\section{Alu-HIV-1 integration PCR}

To examine HIV-1 DNA integration, semi-quantitative nested Alu-LTR PCR was done as described previously $[31,42]$. The following primers were used for the first round of amplification:

Alu-gag (Alu Forward):

5'GCCTCCCAAAGTGCTGGGATTACAG3'

Alu-gag (gag Reverse):

5'GTTCCTGCTATGTCACTTCC-3'

The primers for second round were;
RU5 ( $R$ forward):

\author{
5'-TTAAGCCTCAATAAAGCTTGC C-3' \\ RU5 (U5 Reverse): \\ 5'-GTTCGGGCGCCACTGCTAGA-3'
}

Genomic DNA (200 ng) prepared from TZM-bl cells infected with $\mathrm{HIV}-1_{\mathrm{NL} 4.3}$ in presence or absence of $\mathrm{n}$ butanol fraction prepared from $A$. catechu or Raltegravir (integrase inhibitor) was used as a template for amplification with the first set of Alu-HIV-1 PCR primers in a $25 \mu \mathrm{l}$ PCR mix. Amplification cycles were $95^{\circ} \mathrm{C}$ for $5 \mathrm{~min}$ followed by 39 cycles of $95^{\circ} \mathrm{C}$ for $15 \mathrm{sec}, 50^{\circ} \mathrm{C}$ for $15 \mathrm{sec}$, and $72^{\circ} \mathrm{C}$ for $3.5 \mathrm{~min}$. In the nested step, $4.0 \mu \mathrm{l}$ of the first PCR product was used as a template in a $25 \mu \mathrm{l}$ reaction volume and was amplified for 35 cycles using a similar PCR protocol as noted earlier. GAPDH was amplified as an internal control from 200 ng genomic DNA as a template using the cycle program as $95^{\circ} \mathrm{C}$ for $10 \mathrm{~min}$ followed by 39 cycles of denaturation at $95^{\circ} \mathrm{C}$ for $30 \mathrm{sec}, 60^{\circ} \mathrm{C}$ for $40 \mathrm{sec}$, and $72^{\circ} \mathrm{C}$ for $40 \mathrm{sec}$. The amplified PCR products were resolved on $2 \%$ agarose gel and visualized by ethidium bromide staining.

\section{HIV-1 reverse transcriptase (RT), protease and integrase inhibition assays}

The inhibitory activity of the active n-butanol fraction of A. catechu on HIV-1 RT, protease and integrase was determined as per the manual's instructions of the respective kits (RT assay kit from Roche Applied Sciences, Mannheim, Germany; Protease assay kit from Anaspec, CA, USA and Integrase Assay kit from XpressBio, Life Science Products, MD, USA; http://www.xpressbio.com/ sites/default/files/EZ-1700hiv_integrase_wildtype_kit\%20v \%203.0_pi_061411_0.pdf).

\section{Tat-inhibitor assay}

TZM-bl cells $\left(4.0 \times 10^{4} /\right.$ well $)$ were seeded in 24 -well plate and cultured overnight. The cells were transfected with pTat (0.1 $\mu \mathrm{g}$ /well; ARRRP, USA) using Lipofectamine reagent (Invitrogen) according to the manufacturer's instructions. After $4 \mathrm{~h}$ of transfection, cells were treated with the active plant fraction at $37^{\circ} \mathrm{C}$. Forty-eight hours post-treatment, luciferase activity was measured as described above.

\section{Quantitative reverse transcriptase-polymerase chain reaction ( $q R T-P C R)$}

Total RNA was isolated using the Tri reagent (Sigma Aldrich Inc.) following the standard protocol from TZM-bl cells transfected with pTat as described above. The isolated RNA $(1 \mu \mathrm{g})$ was used to prepare the cDNA using random hexamers, dNTP mixture, RT buffer and Superscript III reverse transcriptase following the manufacturers' protocol. The expression level of mRNA has been 
verified by qRT-PCR using luciferase gene specific primers. The forward and reverse primers used were $5^{\prime}$ ACCGCAAGTGGGGCTTCTGC 3' and 5' CGTGGCC AAACTCGTGGGCT 3', respectively. The PCR parameters used were initial denaturation for $10 \mathrm{~min}$ at $95^{\circ} \mathrm{C}$, and 40 cycles of $95^{\circ} \mathrm{C}$ for $15 \mathrm{~s}$ followed by amplification for $1 \mathrm{~min}$ at $62^{\circ} \mathrm{C}$. Average threshold cycle $(\mathrm{Ct})$ values for $18 \mathrm{~S}$ rRNA (run in parallel reactions to the genes of interest) were used to normalize the average $\mathrm{Ct}$ values of the gene of interest. These values were used to calculate the average for each group from different experiments and the relative $\delta \mathrm{Ct}$ was used to determine the change in the expression between the groups.

\section{Tat-electrophoretic mobility shift assay (EMSA)}

Tat-EMSA was performed using TAT-EMSA kit (Panomics, Inc., Redwood City, CA, USA), following user's manual. Biotin labelled transactivation factor (TF, transactivating regulatory protein) and cold (unlabelled) TF DNA probes were provided by the manufacturer [32]. Nuclear extracts that served as a source of Tat protein were prepared from transfected TZM-bl cells. TZM-bl cells were transfected with pTat as described above. Cells were washed twice with PBS and nuclear extracts were prepared using NEPER Nuclear and Cytoplasmic Extraction Kit (Pierce, Rockford, IL, USA). Protein concentration was determined by the BCA protein estimation kit (Pierce). Briefly, TF DNA probe was incubated with nuclear extract $(4 \mu \mathrm{g})$ for $30 \mathrm{~min}$ either in the presence of $\mathrm{n}$-butanol fraction $(50 \mu \mathrm{g} / \mathrm{ml})$ of $A$. catechu or cold TF DNA probe provided in the kit. To determine the mobility shift of the DNA probe in presence or absence of plant fraction/cold DNA probe, the samples were run in a non-denaturing polyacrylamide gel, as suggested by the manufacturer at $120 \mathrm{~V}$ until the dye had migrated $2 / 3$ of the way down the gel. The gel was then transferred to a nylon membrane, UVcross linked and biotin-labelled DNA was detected by chemiluminescence.

\section{Safety studies of plant extracts and n-butanol fraction Cytotoxicity assessment by MTT assay}

Cytotoxicity of extracts/fractions was assessed using MTT [3-(4,5-dimethylthiazol-2-yl)-2,5-diphenyltetrazolium bromide; Sigma-Aldrich Inc.] assay [43]. Briefly, TZM-bl cells $\left(6.0 \times 10^{3} /\right.$ well $\left./ 100 \mu \mathrm{l}\right)$ were seeded in a 96-well culture plate (Greiner Bio-One, $\mathrm{GmbH}$, Frickenhausen, Germany) and grown overnight at $37^{\circ} \mathrm{C}$ in a humidified atmosphere of $5 \% \mathrm{CO}_{2}$. Next day, culture medium with increasing concentrations of various extracts/fractions was added in duplicate and further incubated for $48 \mathrm{~h}$. Appropriate solvents, used to prepare various extracts/fractions were included as negative controls. After incubation, $20 \mu \mathrm{l}$ of MTT reagent $(5 \mathrm{mg} / \mathrm{ml}$ ) was added per well and incubated at $37^{\circ} \mathrm{C}$ for $3 \mathrm{~h}$ followed by addition of MTT solvent (100 $\mu \mathrm{l} /$ well; $20 \%$ SDS and 50\% dimethyl formamide in $50 \mathrm{mM}$ PBS). The absorbance (OD) was read at $570 \mathrm{~nm}$ with reference filter at $690 \mathrm{~nm}$. Cell viability was calculated using the equation,

$$
\begin{aligned}
\% \text { Viability }= & \left(\mathrm{OD}_{\text {Extract }} \text { fraction treated cells } / \mathrm{OD}_{\text {Untreated cells }}\right) \\
& \times 100
\end{aligned}
$$

\section{Estimation of pro-inflammatory cytokines secreted by human cervico-vaginal keratinocytes}

To study, if plant extracts/fractions induce epithelial toxicity and inflammation, their impact on a human cervico-vaginal keratinocyte cell line (Vk2/E6E7) viability and analysis of pro-inflammatory cytokines secretion was done. Cervico-vaginal Vk2/E6E7 cells $\left(6.0 \times 10^{3} /\right.$ well) were seeded in 96-well culture plate and incubated in humidified atmosphere of $5 \% \mathrm{CO}_{2}$ at $37^{\circ} \mathrm{C}$ for $24 \mathrm{~h}$. After incubation, cells were treated with varying concentrations of plant extracts for $24 \mathrm{~h}$ and culture supernatant was collected for various cytokines quantitation using BDTM Cytometric Bead Array kit (BD FACSCanto Flow Cytometer; BD Biosciences Pharmigen, San Diego, CA, USA). The kit allowed simultaneous quantification of interleukin-10 (IL-10), IL-12 (p70), IL-1 $\beta$, IL-6, IL-8 and tumor necrosis factor (TNF). The cytokine bead assay was performed according to the manufacturer's specifications and data analysis was done using BD FACSDiva software. In addition, Vk2/E6E7 cells viability after $24 \mathrm{~h}$ treatment with test extracts and n-butanol fraction was also determined by MTT assay as described above.

\section{Transepithelial resistance (TER) measurement}

Epithelial cells monolayer integrity, lining the reproductive tract is critical for the prevention of sexual transmission of HIV-1. Transepithelial resistance (TER), a measure of epithelial integrity, was performed. Caco-2 /HEC-1A cells $\left(5.0 \times 10^{5} /\right.$ well $)$ were grown in appropriate medium $(1 \mathrm{ml})$ in the apical chamber of transwell plates and culture medium $(1.5 \mathrm{ml})$ was dispensed in the basolateral compartment of each well. The cells were allowed to grow for $36-48 \mathrm{~h}$ in $5 \% \mathrm{CO}_{2}$ at $37^{\circ} \mathrm{C}$ and assessed for formation of monolayer by measuring TER. Resistance was measured using Millicell-ERS voltmeter (EMD Millipore Corporation, Billerica, MA, USA) each day until resistance reached plateau. After formation of monolayer, the plant n-butanol fraction $(50 \mu \mathrm{g} / \mathrm{ml})$ was added in the culture medium and was further incubated in humidified atmosphere of $5 \% \mathrm{CO}_{2}$ at $37^{\circ} \mathrm{C}$. Resistance was measured at $30 \mathrm{~min}, 1,2,4,8$ and $24 \mathrm{~h}$ after addition of either n-butanol fraction from A. catechu or nonoxynol-9. 


\section{Calculation of percent inhibition of infection}

Percent inhibition was calculated from luciferase/p24 content, utilizing the following formula:

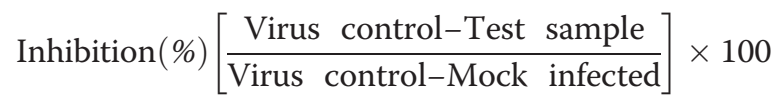

\section{Statistical analysis}

All studies were performed at least three times except where noted in the figures legend. Means and their standard errors are shown. Analyses of concentration-response data were performed by the use of nonlinear curve-fitting program Prism to determine $\mathrm{CC}_{50}$ and $\mathrm{IC}_{50}$ values. Student's $t$-test was used for quantitative variables for comparison between the different groups.

\section{Conclusion}

In conclusion, the extracts prepared from the stem bark of A. catechu exhibited potent anti-HIV-1 effect as demonstrated using different in vitro assays including human peripheral blood lymphocytes. However, the active components responsible for the activity are yet to be explored. The suppression of HIV-1 infection may be, in part due to its inhibitory effect on HIV-1 protease and partly due to the interference in interaction of viral Tat protein to the HIV-1 promoter sequence of LTR, which is also reflected by the expression of gene (luciferase) that is under the control of Tat-LTR mediated transactivation. Initial safety studies of the active n-butanol fraction from $50 \%$ ethanolic extract using vaginal keratinocytes for pro-inflammatory cytokines secretion and dual chamber model for epithelial toxicity indicates that the stem bark extract of the plant have the potential to be developed as an anti-HIV-1 microbicide candidate. Multiple mode of action of this plant has an added advantage and suggests that further safety and efficacy studies using in vivo models are needed. Several attempts have been made at screening numerous traditional plants as medicines in search for plant based anti-HIV-1 agents. However, this is the first report for investigation of $A$. catechu stem bark extracts for its antiHIV-1 activity, where we showed its in vitro anti-HIV-1 property through the inhibition of both HIV-1 protease and LTR-Tat protein interaction. The active extracts, $\mathrm{n}$-butanol fraction and catechins being less toxic confirm the specific inhibition against HIV-1 infection. In the studies done by Marquez et al., [44], anti-viral compounds derived from plants that interfere with HIV-1 LTR promoter regulatory proteins are not likely to generate drugresistant HIV-1 strains, hence suggesting the important role of this plant as a traditional medicine. Further studies to identify the active constituents from $A$. catechu responsible for anti-HIV-1 activity are in progress.

\section{Additional files}

Additional file 1: Figure S1. HPLC profiles of extracts from stem bark
of A. catechu. X-axis represents time and Y-axis represents voltage.
Solvent used was: Acetonitrile: $\mathrm{H}_{2} \mathrm{O}$ (18: $82 \mathrm{v} / \mathrm{v}$; $0.5 \%$ acetic acid); at
$280 \mathrm{~nm}$; a) 50\% Ethanolic extract; b) Aqueous extract.

Additional file 2: Figure S2. HPLC of fractions of 50\% ethanolic stem bark of $A$. catechu. X-axis represents time (in mins), whereas $Y$-axis represents the absorbance at $280 \mathrm{~nm}$; Solvent: Acetonitrile: $\mathrm{H}_{2} \mathrm{O}(18: 82 \mathrm{v} /$ v; $0.5 \%$ acetic acid); a) Petroleum ether soluble fraction; b) Chloroform soluble fraction; c) n-Butanol soluble fraction.

Additional file 3: Figure S3. Cytotoxicity of n-butanol fraction on PBLs. The figure shows the cytotoxicity of n-butanol fraction from $A$. catechu on HIV-1 ${ }_{\text {NL4.3 }}$ infected PBLs after 5 days treatment determined by MTT assay as described in Materials and Methods. Y-axis shows the percent viability of cells.

Additional file 4: Figure S4. Mechanism of inhibition by $n$-butanol fraction at pre-integration steps of HIV-1. A) Env-mediated cell based fusion assay. A cell-based fusion assay was used to mimic the gp120-CD4 mediated fusion of the viral and host cell membranes. $\mathrm{HL} 2 / 3$ cells were pre-incubated with n-butanol fraction from A. catechu $(25 \mu \mathrm{g} / \mathrm{ml})$ prior to incubation with untreated TZM-bl cells for fusion. Bicyclam $(1 \mu \mathrm{g} / \mathrm{ml})$ was used as positive reference control. B) The effect of n-butanol fraction of A. catechu against HIV-1 Reverse Transcriptase (RT) activity at $50 \mathrm{ug} / \mathrm{ml}$ as compared with the reference control, Nevirapine $(1 \mu \mathrm{M})$. Y-axis represents the percent inhibition. C) The inhibitory activity of n-butanol fraction on HIV-1 integrase activity at $50 \mu \mathrm{g} / \mathrm{ml}$ and sodium azide (1.5\%) used as positive control. Y-axis represents the percent inhibition in HIV-1 integrase activity. Values are expressed as mean \pm SE of 2 different experiments performed in duplicates.

\section{Abbreviations}

HIV-1: Human immunodeficiency virus-1; HPLC: High performance liquid chromatography; LTR: Long terminal repeat; IL: Interleukin; RT: Reverse transcriptase; TLC: Thin layer chromatography; MOI: Multiplicity of infection.

\section{Competing interests}

The authors declare that they have no competing interests.

\section{Authors' contributions}

SKG designed and coordinated the overall study and wrote the manuscript. SM coordinated with SK, AKS and SKS for collection and extraction of plant material. SM and SK isolated and characterized the compounds from the $50 \%$ stem bark extract of A. catechu. SKG, N and CSD designed and performed the anti-HIV-1 efficacy and safety experiments. MM helped in performing the experiments as well as data analysis. UR and AV prepared and titrated clinical isolates of HIV-1. All authors read and approved the final manuscript.

\section{Acknowledgements}

This study was financially supported by the research grants from the Department of Biotechnology, Government of India and Indian Council of Medical Research, Government of India. Nutan is a recipient of HIV Research Trust Fellowship provided by HIV Research Trust, UK. The views expressed by the authors, do not necessarily reflect the views of the funding agencies. The authors thank NIH AIDS Research \& Reference Reagent program, Division of AIDS, NIAID, NIH for providing us the molecular clone of HIV-1 $1_{\mathrm{NL} 4.3}$ and pTat expression vector.

\section{Author details}

${ }^{1}$ Reproductive Cell Biology Laboratory, National Institute of Immunology, Aruna Asaf Ali Marg, New Delhi 110 067, India. ${ }^{2}$ Magee-Womens Research Institute, University of Pittsburgh, Pittsburgh, PA 15213, USA. ${ }^{3}$ National Botanical Research Institute, Rana Pratap Marg, Lucknow-226 001, Uttar Pradesh, India. ${ }^{4}$ HIV-AIDS Lab, Molecular Biology and Genetics Unit, Jawaharlal Nehru Centre for Advanced Scientific Research, Jakkur, Bangalore 560 064, India. 
Received: 5 June 2013 Accepted: 11 October 2013

Published: 18 October 2013

\section{References}

1. Volberding PA, Deeks SG: Antiretroviral therapy and management of HIV infection. Lancet 2010, 376:49-62.

2. Menendez-Arias L: Molecular basis of human immunodeficiency virus drug resistance: an update. Antiviral Res 2010, 85:210-231.

3. Vlietinck AJ, De Bruyne T, Apers S, Pieters LA: Plant-derived leading compounds for chemotherapy of human immunodeficiency virus (HIV) infection. Planta Med 1998, 64:97-109.

4. Bedoya LM, Sanchez-Palomino S, Abad MJ, Bermejo P, Alcami J: Anti-HIV activity of medicinal plant extracts. J Ethnopharmacol 2001, 77:113-116.

5. Cos P, Maes L, Vlietinck A, Pieters L: Plant-derived leading compounds for chemotherapy of human immunodeficiency virus (HIV) infection - an update (1998-2007). Planta Med 2008, 74:1323-1337.

6. Chinsembu CK, Hedimbi M: Ethnomedicinal plants and other natural products with anti-HIV active compounds and their putative modes of action. Int J Biotech Mol Biol Res 2010, 1:74-91.

7. Coffin J, Hiughes S, Varmus H: Retroviruses Plainview. NY USA: Cold Spring Harbor Laboratory Press; 1997.

8. Mitchell RS, Beitzel BF, Schroder AR, Shinn P, Chen H, Berry CC, Ecker JR, Bushman FD: Retroviral DNA integration: ASLV, HIV, and MLV show distinct target site preferences. PLOS Biol 2004, 2:E234

9. Cullen BR, Greene WC: Regulatory pathways governing HIV-1 replication. Cell 1989, 58:423-426.

10. el Kharroubi A, Piras G, Zensen R, Martin MA: Transcriptional activation of the integrated chromatin-associated human immunodeficiency virus type 1 promoter. Mol Cell Biol 1998, 18:2535-2544.

11. Rabson $A B$, Lin HC: NF-kappa $B$ and HIV: linking viral and immune activation. Adv Pharmacol 2000, 48:161-207.

12. Rusnati M, Presta M: HIV-1 Tat protein: a target for the development of anti-AIDS therapies. Drugs Future 2002, 27:481-493.

13. Li X, Wang H, Liu C, Chen R: Chemical constituents of Acacia catechu. Zhongguo Zhong Yao Za Zhi 2010, 35:1425-1427.

14. Li XC, Liu C, Yang LX, Chen RY: Phenolic compounds from the aqueous extract of Acacia catechu. J Asian Nat Prod Res 2011, 13:826-830.

15. Burnett BP, Jia Q, Zhao Y, Levy RM: A medicinal extract of Scutellaria baicalensis and Acacia catechu acts as a dual inhibitor of cyclooxygenase and 5-lipoxygenase to reduce inflammation. J Med Food 2007, 10:442-451.

16. Ismail S, Asad M: Immunomodulatory activity of Acacia catechu. Indian J Physiol Pharmacol 2009, 53:25-33

17. Tseng-Crank J, Sung S, Jia Q, Zhao Y, Burnett B, Park DR, Woo SS: A medicinal plant extract of Scutellaria baicalensis and Acacia Catechu reduced LPS-stimulated gene expression in immune cells: $A$ comprehensive genomic study using QPCR, ELISA, and microarray. J Diet Supp/ 2010, 7:253-272.

18. Negi BS, Dave BP: In Vitro antimicrobial activity of Acacia catechu and its phytochemical analysis. Indian J Microbiol 2010, 50:369-374.

19. Guleria S, Tiku AK, Singh G, Vyas D, Bhardwaj A: Antioxidant activity and protective effect against plasmid DNA strand scission of leaf, bark, and heartwood extracts from Acacia catechu. J Food Sci 2011, 76:959-964.

20. Azad-Chowdhury AK, Khaleque RA, Chakder SK: Antifertility activity of a traditional contraceptive pill comprising Acacia catechu, A. Arabica \& Tragiain volucerta. Indian J Med Res 1984, 80:372-374.

21. Yang Q, Stephen AG, Adelsberger JW, Roberts PE, Zhu W, Currens MJ, Feng Y, Crise BJ, Gorelick RJ, Rein AR, Fisher RJ, Shoemaker RH, Sei S: Discovery of small-molecule human immunodeficiency virus type 1 entry inhibitors that target the gp120-Binding domain of CD4. J Virol 2005, 79:6122-6133.

22. Balda MS, Whitney JA, Flores C, Gonzalez S, Cereijido M, Matter K: Functional dissociation of paracellular permeability and transepithelial electrical resistance and disruption of the apical-basolateral intramembrane diffusion barrier by expression of a mutant tight junction membrane protein. J Cell Biol 1996, 134:1031-1049.

23. Beer BE, Doncel GF, Krebs FC, Shattock RJ, Fletcher PS, Buckheit RW Jr, Watson K, Dezzutti CS, Cummins JE, Bromley E, Richardson-Harman N, Pallansch LA, Lackman-Smith C, Osterling C, Mankowski M, Miller SR, Catalone BJ, Welsh PA, Howett MK, Wigdahl B, Turpin JA, Reichelderfer P: In vitro preclinical testing of nonoxynol-9 as potential anti-human immunodeficiency virus microbicide: a retrospective analysis of results from five laboratories. Antimicrob Agents Chemother 2006, 50:713-723.

24. Ray D, Sharatchandra KH, Thokchom IS: Antipyretic, antidiarrhoel, hypoglycaemic and hepatoprotective activities of ethyl acetate extract of Acacia catechu wild in albino rats. Indian J Pharmacol 2006, 38:408-413.

25. Monga J, Chauhan CS, Sharma M: Human epithelial carcinoma cytotoxicity and inhibition of DMBA/TPA induced squamous cell carcinoma in Balb/c mice by Acacia catechu heartwood. J Pharm Pharmacol 2011, 63:1470-1482.

26. Lam SK, Ng TB: Acaconin, a chitinase-like antifungal protein with cytotoxic and anti-HIV-1 reverse transcriptase activities from Acacia confusa seeds. Acta Biochim Pol 2010, 57:299-304.

27. Shen D, Wu Q, Wang M, Yang Y, Lavoie EJ, Simon JE: Determination of the predominant catechins in Acacia catechu by liquid chromatography/ electrospray ionization-mass spectrometry. J Agric Food Chem 2006, 54:3219-3224

28. Nakane H, Fukushima M, Ono K: Differential inhibition of reverse transcriptase and various DNA polymerases by digallic acid and its derivatives. J Nat Prod 1990, 53:1234-1240.

29. Moore PS, Pizza C: Observations on the inhibition of HIV-1 reverse transcriptase by catechins. Biochem J 1992, 288:717-719.

30. Zhao Y, Jiang F, Liu P, Chen W, Yi K: Catechins containing a galloyl moiety as potential anti-HIV-1 compounds. Drugs Discov Today 2012, 17:630-635.

31. Mehla R, Bivalkar-Mehla S, Chauhan A: A flavonoid, luteolin, cripples HIV-1 by abrogation of tat function. PLoS One 2011, 6:e27915.

32. Southgate CD, Green MR: The HIV-1 Tat protein activates transcription from an upstream DNA-binding site: implications for Tat function. Genes Dev 1991, 5:2496-2507.

33. Dandekar DH, Ganesh KN, Mitra D: HIV-1 Tat directly binds to NFkappaB enhancer sequence: role in viral and cellular gene expression. Nucleic Acids Res 2004, 32:1270-1278.

34. Fichorova RN, Zhou F, Ratnam V, Atanassova V, Jiang S, Strick N, Neurath AR: Anti-human immunodeficiency virus type 1 microbicide cellulose acetate 1,2-benzene dicarboxylate in a human in vitro model of vaginal inflammation. Antimicrob Agents Chemother 2005, 49:323-335.

35. Poli G, Bressler P, Kinter A, Duh E, Timmer WC, Rabson A, Justement JS, Stanley S, Fauci AS: Interleukin 6 induces human immunodeficiency virus expression in infected monocytic cells alone and in synergy with tumor necrosis factor alpha by transcriptional and post-transcriptional mechanisms. J Exp Med 1990, 172:151-158.

36. Narimatsu R, Wolday D, Patterson BK: IL-8 increases transmission of HIV type 1 in cervical explant tissue. AIDS Res Hum Retroviruses 2005, 21:228-233.

37. Rohan LC, Moncla BJ, Kunjara Na Ayudhya RP, Cost M, Huang Y, Gai F, Billitto N, Lynam JD, Pryke K, Graebing P, Hopkins N, Rooney JF, Friend D, Dezzuti CS: In vitro and ex vivo testing of tenofovir shows it is effective as an HIV-1 microbicide. PLoS One 2010, 5:e9310.

38. Kappes JC, Wu X: Cell-based method and assay for measuring the infectivity and drug sensitivity of immuno-deficiency virus. United States Patent US 2004, 6:797,4622 B1.

39. Kurarmoto H, Hamano M, Imai M: HEC-1 cells. Hum Cell 2002, 2:81-95.

40. Fichorova RN, Rheinwald JG, Anderson DJ: Generation of papilloma virus-immortalized cell lines from normal human ectocervical, endocervical and vaginal epithelium that maintain expression of tissue specific differentiation proteins. Biol Reprod 1997, 57:847-855.

41. Ciminale V, Felber BK, Campbell M, Pavlakis GN: A bioassay for HIV-1 based on Env-CD4 interaction. AIDS Res Hum Retroviruses 1990, 6:1281-1287.

42. Liszewski MK, Yu JJ, O'Doherty U: Detecting HIV-1 integration by repetitive-sampling Alu-gag PCR. Methods 2009, 47:254-260.

43. Mosmann T: Rapid colorimetric assay for cellular growth and survival: application to proliferation and cytotoxicity assays. J Immunol Methods 1983, 65:55-63.

44. Marquez N, Sancho R, Bedoya LM, Alcami J, Lopez Perez JL, Feliciano AS, Fiebich BL, Munoz E: Mesuol, a natural occurring 4-phenylcoumarin, inhibits HIV-1 replication by targeting the NF-kappa B pathway. Antiviral Res 2005, 66:137-145.

doi:10.1186/1743-422X-10-309

Cite this article as: Nutan et al:: Extracts from Acacia catechu suppress HIV-1 replication by inhibiting the activities of the viral protease and Tat. Virology Journal 2013 10:309. 